Does context matter for Sustainability Disclosure? Institutional factors in Southeast Asia

(Short Title: Institutions and Sustainability Disclosure)

Paper accepted by the Business Ethics: A European Review Journal

January 2020

Mi Tran

(Corresponding author)

Huddersfield Business School
University of Huddersfield
Queensgate
Huddersfield HD1 3DH
United Kingdom
E-mail: t.tran@hud.ac.uk

Eshani S. Beddewela

Huddersfield Business School

University of Huddersfield

Queensgate

Huddersfield HD1 3DH

United Kingdom

E-mail: e.s.beddewela@hud.ac.uk

Keywords: sustainability disclosure (SD), institutional theory, institutions; regulative; normative; cultural-cognitive; Southeast Asia 


\title{
Does context matter for Sustainability Disclosure? Institutional factors in Southeast Asia
}

\begin{abstract}
Corporate sustainability is a dynamic, socially constructed concept. Relatedly, to understand the variations in the disclosure of corporate sustainability activities across countries, we need to inherently explore their underlying socio-political contexts. At present our understanding in this regard, is deficient. We respond to this extant research gap by adopting a multi-country approach to investigate the relationship between countries' institutional environments and firms' sustainability disclosure (SD) practices, across six countries in the Southeast Asian region. Our findings reflect a common focus of Southeast Asian firms on community and human resources related disclosures. Nevertheless, nuanced differences in their overall SD levels confirm the influence of differing legal, normative and socio-cultural systems in engendering greater disclosure and transparency at a national level. By quantifying the institutional environment and identifying external influencing factors, our study provides a useful framework grounded in neo-institutional theory to widen the existing understanding of how institutional pressures can be measured and compared across different contexts.
\end{abstract}

Keywords: sustainability disclosure (SD), institutional theory, institutions; regulative; normative; cultural-cognitive; Southeast Asia 


\section{INTRODUCTION}

Corporate sustainability has been at the forefront of business firms' corporate agendas during the last decade. Its integration of 'social and environmental concerns within business operations and their interactions with stakeholders' makes corporate sustainability complex, multi-faceted and inherently context-specific (Fassin et al., 2015; Marrewijk \& Werre, 2003, p.107). There are also differences in the types of corporate sustainability issues being addressed across countries (Maon, Swaen \&Lindgreen, 2017; Welford, 2005), primarily as a result of country-level institutional differences (Campbell, 2007; Chapple \& Moon, 2005; Hahn \& Kuhnen, 2013; Williams \& Aguilera, 2008). However, our understanding of how a country's institutions influence corporate sustainability, is largely limited at present to Western countries (Kim \& Moon, 2015).

In this regard, regions such as Asia, not only present nuanced differences in their national institutional environments, such as the role of state, power concentration in countries' economic, political, ethical and religious systems (Kim \& Moon, 2015), but also consist of dynamic socioeconomic systems (Gond \& Moon, 2011). For instance, countries in the South East Asia (SEA), a sub-region in Asia, which has diverse socio-economic issues, ranging from poverty, climate change, to human rights violations, child labour and corruption (Belal, Cooper \& Roberts, 2013) have proactively undertaken institutional reforms to influence corporate sustainability practices (Srinivasan, 2011). Nevertheless, as extant research examining institutional influences on corporate sustainability in non-western regions, is limited to single country studies (See Janggu et al., 2014; Hermawan \& Gunardi, 2019; Hu \& Loh, 2018; Zahid, Ghazali \& Rahman, 2016), we do not have a comparative cross-country level understanding of how country-level institutional influences could differ between countries within a non-western region (Fifka \& Drabble, 2012; Vashcheko, 2017), and how those influences could engender corporate sustainability practices, specifically that of sustainability disclosure (SD) in that region (Patten \& Shin, 2019; Tilt, 2016).

We therefore adopt a multi-country approach to examine the relationship between the institutional environment (depictive of institutional pressures) and firms' SD practices. We focus our study upon six South East Asian (SEA) countries; Indonesia, Malaysia, Philippines, Singapore, Thailand

and Vietnam, representative of the most dynamic economies in the region (Amran et al., 2016). These countries consist of different institutional environments, with divergent legal environments, 
levels of economic development, population sizes, religious affiliations and languages, which makes them an ideal study context to examine how country-level institutional influences could engender sustainability disclosure (SD).

Our study therefore contributes to extant literature in the following ways; first, by locating our study within the SEA region, we extend the existing discussion in global comparative sustainability literature by addressing extant gaps in data in relation to SD from a non-western, perspective (Jamali, 2016; O'Connor, Parcha \& Tulibaski, 2017). Second, we also address calls by researchers to consider the importance and relevance of 'institutional nestedness and configurations in shaping nonmarket outcomes' such as SD (Jamali \& Carroll, 2017, p.323; Hartmann \& Uhlenbruck, 2015), by identifying commonalities and nuanced differences in institutional influences across countries in relation to SD (Brammer, Jackson \& Matten, 2012; Khan, Lew \& Park, 2015; Reimann et al., 2012).

Third, by measuring multiple institutional pressures derived from neo-institutional theory (See Gauthier, 2013; Hahn \& Kuhnen, 2013; Miska, Szocs \& Schiffinger, 2018; Smith, Haniffa \& Fairbrass, 2011), and constructed upon the three pillars of institutions; regulative (depicted as those pressures exerted by country-level legal systems and regulations), normative (identified to be pressures placed by international standards and business associations) and cultural-cognitive (identified as pressures engendered by the national culture) (Scott, 1995), we address extant research deficiencies in focusing upon a single institutional force (Kim et al., 2013), thus ignoring the influence of multiple institutional influences upon SD (Aguinis \& Glavas, 2012; MartinezFerrero and Garcia-Sanchez, 2017). Herein, we acknowledge the need to not only identify institutional factors but also to measure the extent of their influence upon companies' SD practices (Mainardes, Alves \& Raposo, 2011; Matten and Moon, 2008). Potentially, our approach to the measurement of institutional pressures in this study, therefore, offers an alternative framework in identifying external influencing factors thus, widening the existing understanding of how institutional pressures can be measured and compared across different contexts (Jamali \& Carroll, 2017). 
The remainder of the paper is structured as follows. In the next section, we present the definition of SD and a review of the current literature. We then provide a summary of the context of sustainability and SD in SEA. Subsequently we focus on discussing the theoretical framework based on which institutional factors are identified and relevant hypotheses are developed. Next, we describe the research design and report the empirical results. The paper concludes with a discussion and summary of our main findings.

\section{LITERATURE REVIEW}

Corporate sustainability disclosure has become an important and urgent issue for corporations (Belal \& Momin, 2009; Waller and Lanis, 2009), largely due to increased stakeholder pressures for corporate accountability pertaining to their social and ecological impacts (Vachon, 2010; Vehkapera, 2004). Nevertheless, the definition and scope of Sustainability Disclosure (SD) remains diverse, with the use of multiple terminologies, such as Corporate Social Responsibility Disclosure (CSRD), CSR reporting, sustainability reporting and social auditing (Gray, 2002; Parker, 1986). We conceptualise SD as information that firms disclose to communicate with stakeholders regarding the social and environmental impacts of their corporate performance (Schreck \& Raithel, 2018). It comprises of diverse issues (Gray, Kouhy \& Lavers, 1995), such as information about the products, labour and environmental effects of corporate practices and their political and charitable contributions, etc. (Williams, 1999).

Extant SD literature focusing on why companies disclose sustainability information (De Villiers \& Alexander, 2014), have investigated its nature, patterns (e.g. Buhr \& Freedman, 2001) and determinants (e.g. Chakroun \& Matsoussi, 2012; El-Halaby \& Hussainey, 2015; Ghazali, 2007). In this regard, factors such as organisational characteristics, such as firm size (See Esa \& Ghazali, 2012; Mio \& Venturelli, 2013; Rahman, Zain \& Al-Haj, 2011), profitability (See Anas, Rashid \& Annuar, 2015; Cowen et al., 1987; El-Halaby \& Hussainey, 2015), industry type (See Chan, Watson \& Woodliff, 2014; Naser \& Hassan, 2013; Parsa \& Kouhy, 2008) and corporate governance mechanisms (See Haji, 2013; Jizi et al., 2014; Khan, Muttakin \& Siddiqui, 2013a), have been identified as key determinants of SD. Nevertheless, national institutional environmental influences upon SD, have received much less attention (Jackson \& Apostolakou, 2010; MartinezFerrero \& Garcia-Sanchez, 2017). Although there have been a few studies examining this 
relationship in recent years (See Mzembe, Melissen \& Novakovic, 2019; Rao-Nicholson, Khan \& Marinova, 2019), majority of these studies have been conducted using a qualitative approach which limits the ability to generalise findings above the studied settings.

Given that SD is inherently connected to the broader societal context (Campbell, 2007; Muthuri \& Gilbert, 2011), the lack of focus upon this context, especially from a quantitative perspective, leaves us with a lack of understanding about whether variations of SD across countries can be explained from a contextual view. Nevertheless, as institutional environments are dynamic and complex (Ali, Frynas \& Mahmood, 2017; Gallen \& Peraita, 2018), any research examining their influences upon SD requires a comparative approach. Present SD studies conducted in the SEA region in this regard however, has been dominated by single country case studies (See Janggu et al., 2014; Hermawan \& Gunardi, 2019; Hu \& Loh, 2018; Zahid, Ghazali \& Rahman, 2016).

Thus, in response to these gaps and the call for extending the understanding of how cross-national differences influence organisational sustainability decisions (Jamali \& Carroll, 2017), we move beyond the Western-grounded understanding of sustainability and join other scholars (Jamali, Karam, Yin \& Soudararajan, 2017; Jamali, Lund-Thomsen \& Jeppesen, 2017) to bring context center stage through examining the diverse institutional pressures upon SD, reflective of contextual influences, across six SEA countries to identify how different institutional pressures influence firms' SD practices.

\section{CORPORATE SUSTAINABILITY IN SOUTHEAST ASIA}

Deeply influenced by culture and religion, corporations in SEA has a history of giving back to society. Because of colonialism and war, the classic philanthropy model, such as building hospitals, schools or cultural institutions has been rooted in some countries as a business necessity (Sharma, 2013). It is, therefore, not unfamiliar for corporations to support nation building, through their CSR and sustainability practices. However, the past decade has highlighted endemic sustainable development issues in the region (Belal, Cooper \& Roberts, 2013), with issues such as human rights, raising global concerns about countries in the region (Li et al., 2010). Thus, propagating a culture of corporate sustainability in the region has become an important priority for some of its national governments, leading to an increase in mandatory approaches to sustainability and SD, as outlined in Table 1 below. 


\section{INSERT TABLE 1 ABOUT HERE}

Indirect regulation, in the form of laws on diverse aspects of corporate sustainability practices (such as human resources, environment, products and consumers, etc), and soft regulation such as the use of tax incentives for SD have also been adopted across countries. For example, automatic tax exemptions are provided for companies which engage in charitable donations in Malaysia ( $\mathrm{Lu}$, 2013). However, there are substantial variations in government involvement in engendering SD across the region (Asia-Pacific Economic Cooperation [APEC], 2005). While some governments have been more proactive in creating a regulatory environment which mitigates detrimental corporate socio-environmental impacts, other governments, such as Singapore, adopt nonregulatory measures, such as the promotion of voluntary guidelines and principles alongside diverse public, private, industrial and NGO initiatives.

Other than governments, stock exchanges in the SEA also actively encourages SD. For example, Bursa Malaysia, promotes its Business Sustainability Programme, an environmental, social and corporate governance index, a CSR framework, and the establishment of Institute of Corporate Responsibility Malaysia. Other enablers of corporate sustainability in the region include various voluntary initiatives (e.g. trainings standards, codes and guidelines) promoted by NGOs, national and international standard organisations, such as the Global Reporting Initiative (GRI) and United Nations Global Compact (UNGC) and by industry and/or trade associations.

\section{THEORETICAL FRAMEWORK AND HYPOTHESIS DEVELOPMENT}

Neo-institutional theory focuses on the relationship between companies and the broader societal context (Brammer et al., 2012; Campbell, 2007; Ioannou \& Serafeim, 2014, Peng \& Heath, 1996; Scott, 1995). This societal context, comprises of multiple institutional actors which could influence firms' decision making (Ioannou \& Serafeim, 2012; Peng \& Heath, 1996; Scott, 1995) by exerting pressures and monitoring their behaviours (Baughn, Bodie \& McIntosh, 2007).

Companies pursuing legitimacy could be compelled to align with these diverse institutional pressures, thereby, conforming to social norms and formal laws (Peng, Denis \& Jiang, 2008; 
Weber, 1978). The examination of institutional influences in the field of CSR and sustainability has only emerged since mid-2000s (Aguilera et al., 2007; Campbell, 2007; Jackson \& Apostolakou, 2010). Nevertheless, the theory extends our understanding of, and provides insights into how corporate reporting practices, such as $\mathrm{SD}$, are adopted in different countries and provides a formidable lens with which to conceptualise actors' interactions within a specific socio-political governance system across different geographic contexts (Irvine, 2008). In response to a dearth of research investigating the role of formal and informal institutions on corporate sustainability including its disclosure ( $\mathrm{Li}$ et al., 2010), this study attempts to identify relevant institutional pressures with the use of Scott's framework (1995) to reveal the dynamic interactions between institutions, organisations and SD as an outcome of such interactions. The framework with the three contrasting, interdependent and mutually reinforcing institutional pillars represents the elements in which institutions consist of, and provide different rationales for claiming legitimacy (Scott, 1995, 2008), hence is useful in examining the forces and pressures of institutional environment on firms (Kostova \& Roth, 2002).

\section{Hypotheses development}

\section{Regulative pillar}

Regulative structures are mostly enforced by governments and states through the implementation of laws, rules and regulations, and are therefore, more formal, explicit and legally sanctioned (Bruton, Ahlstrom \& Li, 2010; Palmer, Biggart \& Dick, 2013). Institutions with regulative elements guide behaviours through monitoring and enforcement (North, 1990). The pressure from regulative pillar is often reflected through the legal system (Barakat, Perez \& Ariza, 2015) consisting of two main traditions; common law and civil law (La Porta, Lopez-de-Silanes \& Shleifer, 2008).

These two legal traditions present distinct characteristics that could potentially influence firms' SD practices. Previous studies have observed that the civil law system is more stakeholder-oriented while the common law system focuses on protecting shareholders (Frias-Aceituno et al., 2013a). Countries with a civil law system, therefore, have more comprehensive laws (Amor-Esteban et al., 2017; Frias-Aceituno et al., 2013a; Gallego-Alvarez et al., 2017) giving stakeholders legitimate interests and subsequently greater influence on firms' sustainability behaviour (Garcia-Sanchez et al., 2016). Studies examining the relationship between SD and legal systems, have consistently 
found that firms from civil law countries, with a robust stakeholder governance structure, are more likely to get involved in reporting sustainability information to obtain stakeholders' approval (see Frias-Aceituno et al., 2013a; Smith, Adhikari \& Tondkar, 2005). Thus, our first hypothesis is stated as follows:

Hypothesis 1. Firms from countries with civil law system are expected to disclose more sustainability information than their counterparts from common law countries.

In addition to legal systems, government regulations have been traditionally considered as a form of coercive power and regulatory pressure in which conformity is imposed on social actors (Campbell, 2007, Kim et al., 2013; Scott, 2008). In the light of several corporate scandals and the financial crisis, diverse groups of stakeholders have argued for more active governmental actions in relation to SD to mitigate the high level of distrust toward companies' self-regulatory behaviours (Ioannou \& Serafeim, 2014). Despite criticism against the implementation of hard regulations (Adams \& Frost, 2007; Overland, 2007; Rodriguez \& LeMaster, 2007), mandatory disclosure is expected to impose additional regulatory pressures on firms (Wang et al., 2017), allow nonfinancial stakeholders to increase their demands and potentially enable transfer of wealth from shareholders to other stakeholder groups (Ioannou \& Serafeim, 2014). This type of regulatory commitment may produce an effective institutional justification to initiate changes and create a systematic effect at the societal level to incorporate sustainability and SD considerations into corporate business activities (Eccles, Ioannou \& Serafeim, 2014). A number of empirical studies have provided evidentiary support for the positive influence of mandatory regulations on SD (Othman, Darus \& Arshad, 2011; Pedersen et al., 2013), with consistent increases being seen in relation to the level of SD (Othman et al., 2011) and in the number of companies disclosing sustainability information in annual reports for the first time (Pedersen et al., 2013). Based on these empirical evidence and theoretical arguments, we present our second hypothesis as follows:

Hypothesis 2. Firms from countries with mandatory regulation on disclosure have higher level of $S D$ than firms from the other countries.

\section{Cultural-cognitive pillar}

Cultural-cognitive dimension emphasises the role of shared beliefs, social knowledge and takenfor granted assumptions by people in a country or culture that plays a powerful role in institutional processes (Scott, 2004). Institutions within the cultural-cognitive pillar encourage firm behaviour 
through social pressures and conformity (Shnayder, Rijnsoever \& Hekkert, 2016) justified by orthodoxy according to which the correctness and soundness of underlying actions are perceived (Scott, 2013). As cultural conceptions are plural and nuanced, people interpret situations differently in terms of what is and what ought to be due to the differences in beliefs and expectations (Vitell, Joseph \& Thomas, 2003).

Culture, therefore, imposes differential pressures on firms and shaping firms' legitimacy management strategy including their approach to disclosure and transparency (Garcia-Sanchez et al., 2013; Smith et al., 2005; Ullman, 1985). Indicators of culture such as Hofstede's cultural dimensions, uncertainty avoidance and masculinity, have been argued to be relevant and appropriate for studies related to disclosure practices (Bowrin, 2013; Williams, 1999) due to their link with the subcultural value of secrecy (Gray, 1988). Following this argument, these two dimensions are used in this study to measure the effect of cultural-cognitive pressures on SD.

(i) Uncertainty avoidance

The first dimension, uncertainty avoidance (UA), relates to the extent in which people from a country feel threatened by uncertain situations in future and therefore creates beliefs or institutions that help to avoid these uncertainties (Hofstede, 2001). A small number of studies have investigated the impact of UA dimension in SD with competing perspectives (Adelopo, Moure \& Obalola, 2013; Bowrin, 2013; Garcia-Sanchez et al., 2013). Adelopo et al. (2013) supported the positive relationship between UA and SD with the argument that firms from high UA are more likely to report sustainability information to reduce uncertainties following the society's expectations. In contrast, most studies have hypothesised the negative effect of UA on SD based on the argument that strong UA is aligned with a preference of secrecy, leading to a restriction in disclosure, thus retaining security and avoiding competition as well as conflict (Gray, 1988).

Additionally, as low UA societies are more accepting of change, have less regulations and laws, and are more flexible in their approaches, stakeholders from these societies might have higher demands and expectations for sustainability than high UA societies where such approach are forceful with the support of legislation (Garcia-Sanchez et al., 2016). Hence, companies in countries with lower UA are expected to be more transparent to keep these interest groups informed with social and environmental activities. Aligned with the above arguments, our third hypothesis is developed as follows: 
Hypothesis 3. Firms in countries with high score in UA dimension are expected to have higher level of $S D$.

\section{(ii) Masculinity/ Femininity (MAS)}

High MAS societies pay high value to competition, achievement and success while communities featuring feminine characteristics, indicated by a low score, appear to be more caring and conscious of the influence of their actions on society (Hofstede, 2001). Evidently, previous literature suggests that masculine societies demonstrate less appreciation of cooperative strategies, lack of consideration for social welfare and more tolerance towards the use of unethical practices to achieve profit maximisation (Kang, Lee \& Yoo, 2016; Steensma, Marino \& Weaver, 2000; Tice \& Baumeister, 1985). Firms from these societies may focus more on activities that bring economic success, prioritise financial performance and surviving competition, leading to negative social and environmental responsiveness which is reflected through a lower level of SD engagement (Williams, 1999). In contrast, as the interests of feminine societies reflect stronger stakeholder orientation, firms from these countries are under greater pressure to engage in sustainability (Gray, 1988) and provide disclosure beyond purely financial information (Smith et al., 2005). Therefore, our fourth hypothesis is that:

Hypothesis 4. Firms from countries with femininity characteristics disclose more sustainability information, compared with firms from masculinity countries.

\section{Normative pillar}

The central conception of the normative pillar concerns the influence of shared norms, values and beliefs, representing a predication for future action and an expectation for how actors should behave in a particular situation (Scott, 2013). From an organisational perspective, normative elements influence firms' behaviour through the use of moral or ethical criteria (Shnayder et al., 2016) and the assistance of professional networks, constituting of a system of soft laws (Scott, 2013).

One of the most well-known self-regulation forms (soft laws) is external or industry standards (Christmann \& Taylor, 2006; Shnayder et al., 2016) which construction used to compare and assess structures or behaviours reflects the concept of shared values in the normative pillar (Scott, 2013). In the field of corporate sustainability, Global Reporting Initiative (GRI) standard, with the purpose 
of helping organisations disclose their sustainability activities, has been recognised as a successful institutionalisation project (Brown, de Jong \& Levy, 2009) and a key normative body in SD (Barkemeyer, Preuss \& Lee, 2015; Etzion \& Ferraro, 2010; Levy, Brown \& de Jong, 2010). So far, empirical evidence on the contribution of such standards is lacking (Perez-Batres, Miller \& Pisani, 2010). Examining the effect of GRI, hence, will not only reveal the normative pressure on firms but also help to identify their effectiveness. Our hypothesis is developed as follows:

Hypothesis 5. Firms that follow GRI reporting standard tend to report more sustainability information.

The normative element also guides organisational actions and beliefs developed for professionalisation or social obligation (Hoffman, 1999). Normative pressures often reflect through the accepted values and norms developed within professional networks to provide guidance for corporate conduct and behaviour (Arevalo et al., 2013; Mzembe et al., 2019). Corporations are more likely to act responsibly if there are normative institutions in place that support such behaviour (Galaskiewicz, 1991). For instance, business and professional associations may promote a better understanding of the virtues and benefits of corporate giving, and at the same time put peer pressure on their members to behave more responsibly (Campbell, 2006; Martin, 2002), hence motivating corporations to engage in sustainability and SD (Galaskiewcz, 1991).

Empirical evidence on the role of such associations in exerting normative pressures on firms to adopt sustainability practices is very limited, resulting a dearth of research on the role of nongovernmental and non-corporate organisations as agents in sustainability processes (Schaefer \& Kerrigann, 2008). Our study, hence, contributes to this aspect of the literature by investigating the effect of six associations which are major advocators of sustainability and SD in the studied countries (Appendix 1). Our hypothesis, based on the theoretical argument, is developed as follows:

Hypothesis 6. Firms that have membership with the associations promoting sustainability have higher SD in annual reports compared to their counterparts.

Table 2 provides a rationale for our hypotheses development and a summary of the hypotheses. 


\section{METHODOLOGY}

\subsection{Sample Design and Data Collection}

The study adopts the methodology of the Financial Times Stock Exchange (FTSE)'s ASEAN allstars index which comprises 30 largest and most liquid stocks in each of the six countries in the ASEAN Exchange collaboration, including Thailand, Singapore, Malaysia, Indonesia, Philippines and Vietnam, reflecting the breadth and depth of the ASEAN economy. The choice of largest firms from each country is justified by the need to capture more information about Corporate Sustainability, as large corporations are the main practitioners of SD in the examined countries (Herrera, Roman \& Alarilla, 2011; Lu, 2013) and are deemed to have more resources to implement substantial sustainability practices (Chapple \& Moon, 2005). Moreover, this selection criterion enabled us to obtain data from countries, such as Philippines and Vietnam, where the concept of corporate sustainability is not yet substantial (Chapple \& Moon, 2005; Hieu, 2011), and thereby enabling the completeness within our overall data set.

Modelled on the FTSE ASEAN all-stars index, the sample of 30 largest companies from the six stock exchanges made up a total sampling size of 180 companies. Due to missing annual reports and a number of companies not having a separate report from their headquarters (located in another country), our final sample includes 171 observations. As reliable databases on sustainability information in these countries are unavailable, the annual reports (year ending 2013) from thirty largest listed-companies on each country's stock exchange market were hand-collected and manually analysed to reflect accurately the level of SD across firms. The year of 2013 was chosen for data collection to allow us evaluate the influence of mandatory SD regulation, and thus, the role of coercive pressures, as some of the countries in our sample, for example Indonesia, Malaysia and Philippines, had by this time had mandatory regulations in place for SD. Although we are aware that a larger sample size would allow better generalisability of SD practice in these countries, the labour-intense data collection process has hindered our ability to expand the sample size further.

\subsection{Measurements of variables}

The variables in this study are classified into three main categories, the dependent variable, the independent variables and the control variables. To measure the level of SD, we adopted an equalweighted index of Branco and Rodrigues (2008). The index has been cross-checked and modified with reference to other studies (Abd-Mutalib, Jamil \&Wan-Hussin, 2014; Hummel \& Schlick, 
2016; Islam, Jain \& Thomson, 2016; Nobanee \& Ellili, 2015) to reflect accurately diverse sustainability issues relevant to the studied context. The index includes 30 disclosure items (Appendix 2) with 11 items in environmental disclosure (ED), 9 items in human resources disclosure (HRD), 5 items in products and consumers disclosure (PCD) and 5 items in community disclosure (CD). A company is awarded 1 if an item in the checklist is disclosed and 0 if it is missing. The SDI (Sustainability Disclosure Index) is calculated by the ratio of actual scores awarded to the maximum score that a firm could achieve. In most cases, the maximum number of items is 30 . However, to take into consideration the differences among industries, we adopted the absolute disclosure ratio to ensure that the set of disclosure items is relevant to a corporation based on the industry in which it operates (Marquis \& Toffel, 2012). Certain items, therefore, are excluded for firms from the industries of healthcare services, banking and financial services, hotels, leisure and entertainment.

From the literature review, six institutional factors, including legal system, mandatory reporting, uncertainty avoidance, masculinity, GRI reporting standard and business associations have been identified to present the effect of institutional environment on SD through three pillars, regulative, normative and cultural-cognitive. Following previous studies (see Adelopo et al., 2012; Amran \& Haniffa, 2011; Comyns, 2016; Williams, 1999), all of the institutional factors are measured using dummy variables (Table 2).

To prevent the potential of omitted variables bias, we included several control variables, namely firm size, profitability, leverage, firm age, audit firm size and industry affiliation. Whilst for brevity we do not develop direct theoretical links to support the relationship between these control variables and $\mathrm{SD}$, there are extensive theoretical and empirical literature suggesting the potential impact of these variables on SD (e.g., Amran \& Devi, 2008; Clarke \& Gibson-Sweet, 1999; Khan, 2010; Ntim \& Soobaroyen, 2013; Othman et al., 2011). Table 3 provides a summary of all the variables' measurements and data source.

INSERT TABLE 3 ABOUT HERE 


\section{RESULTS}

\subsection{Descriptive statistics}

Table 4 and 5 report the descriptive statistics of the disclosure indices across the six countries and the distribution of institutional variables. Overall, the SD index scores range from a minimum of $0 \%(0.000)$ to a maximum of $92 \%(0.917)$, with the average firm disclosing $44 \%(0.440)$ of the checklist. Moreover, the mean scores of the SD index emphasises various levels of disclosure across the countries with Thailand having the highest score (0.554), followed by Indonesia (0.552), Malaysia (0.459), Singapore (0.427), Philippines (0.326) and Vietnam (0.302).

\section{INSERT TABLE 4 \& 5 ABOUT HERE}

Singapore, as the only developed country in the group, was expected to have the highest disclosure level, however, is only ranked fourth. This shortcoming in the country's SD might be the result of its socio-economic development, which reduces the motivations and necessities for firms to contribute towards societal and environmental development (Lee, Mak \& Pang, 2012). With stringent regulations and compliance requirements on diverse social and environmental issues, Singapore has made corporate sustainability a compliance matter of high corporate importance (Tan, 2013). Even though we acknowledge that Singaporean firms might disclose their sustainability practices via other channels, we nevertheless argue that our result is also indicative of the potential influences of institutional factors, rather than economic development, attributing to the differences in SD across the countries.

Table 6 presents the coefficients of both Pearson's parametric correlation and Spearman's nonparametric correlation. Out of the six independent variables, legal origin, the two cultural dimensions (uncertainty avoidance and masculinity) and the adoption of GRI standard were found to have significant correlations with the dependent variable, SDI (Sustainability Disclosure Index).

INSERT TABLE 6 ABOUT HERE 


\subsection{Multiple Regression Analysis}

The OLS multiple regression was used to test the hypotheses and measure the extent to which SD index is explained by institutional factors. The multivariate regression model is specified as follows:

$$
\begin{aligned}
\mathrm{SDI}_{\mathrm{i}} & =\beta_{0}+\beta_{1} \mathrm{LEG}_{\mathrm{i}}+\beta_{2} \mathrm{MD}_{\mathrm{i}}+\beta_{3} \mathrm{UA}_{\mathrm{i}}+\beta_{4} \mathrm{MAS}_{\mathrm{i}}+\beta_{5} \mathrm{GRI}_{\mathrm{i}} \\
& +\beta_{6} \mathrm{SASS}_{\mathrm{i}}+\Sigma \beta_{\mathrm{i}} \mathrm{CONTS}_{\mathrm{i}}+\varepsilon_{\mathrm{i}}
\end{aligned}
$$

Where SDI presents the SD index; $L E G$ denotes legal system; $M D$ denotes mandatory disclosure; UA denotes uncertainty avoidance; MAS denotes masculinity; GRI denotes GRI standard; SASS denotes sustainability-related associations; CONTS represents all the control variables, including firm size, leverage, profitability, firm age, audit firm size and industry affiliation.

The main assumptions underlying multiple regressions; linearity, normality, independence of residuals, homoscedasticity and multicollinearity, were tested by using various statistical and visual examinations, including the use of normal probability plots of the residuals, the scatterplots of standardised residuals, Durbin-Watson test, tolerance and VIF values.

\section{INSERT TABLE 7 ABOUT HERE}

Table 7 presents the empirical findings of the regression model (1). Among all the independent variables, four variables, mandatory disclosure (MD), uncertainty avoidance (UA), masculinity (MAS) and the adaption of GRI standard (GRI), are found to have statistically significant relationship with Sustainability Disclosure Index (SDI), in which MD, UA and GRI have positively significant effect while MAS has negative impact on SD. Except for UA, the coefficients' signs of the other three variables are consistent with the expectations. The empirical findings, therefore, offer support for hypotheses 2, 4 and 5. Although the impact of UA is significant, hypothesis 3 cannot be supported as the coefficient's sign is opposite with the expectation. The results of the other independent variables, legal system (LEG) and sustainability-related associations (SASS), were found to be insignificant. Table 8 provides a summary of our findings. 


\section{INSERT TABLE 8 ABOUT HERE}

\subsection{Sensitivity analyses}

Three complementary analyses were performed to ensure the robustness of our findings. First, to check whether the impact of explanatory variables on each category is similar to the main results, the regression model is re-estimated with each of the sub-indices, EDI (Environmental Disclosure Index), HRDI (Human Resources Disclosure Index), PCDI (Products and Consumers Disclosure Index) and CDI (Community Disclosure Index), replaced SDI (Sustainability Disclosure Index) as the dependent variable (Dominguez, 2012; Michelon, 2011). Second, we used an equal-weighted index to measure SDI. However, since the number of items in the sub-indices are substantially different from each other, different weights could be assigned to each sub-index (for instance EDI $36 \%$, HRDI $30 \%$, PCDI 17\% and CDI 17\%), implying that certain categories can be considered as more important than the others. As a result, following previous disclosure studies (Al-Bassam et al., 2015, p.28; Elmagrhi, 2016, p.176; Ntim et al., 2012), an alternative weighted index W-SDI was constructed by giving each of the sub-indices an equal weight of $25 \%$ to ensure the relationship between the institutional variables and SDI is not sensitive to the weight of the four sub-indices. We then re-examined the regression model with the $W-S D I$ replaced the equal-weighted $S D I$ as the dependent variable. The findings of the two sensitivity tests are presented in the table 9. Compared with the empirical findings presented in the table 7 , the results of all models are essentially the same. Therefore, the empirical findings of the main model are relatively robust with the use of subindices and alternative SD proxy.

\section{INSERT TABLE 9 ABOUT HERE}

Third, the inclusion of institutional factors such as mandatory disclosure (MD), the adoption of GRI standard (GRI) and membership of sustainability-related associations (SASS) poses a potential endogeneity problem. To address this concern, we conducted two-stage Instrumental Variables (IV) regression. For mandatory disclosure, wealth measured by the countries' average 
per capita GDP in 2013 from World Bank database is used as an instrument variable, following suggestions of Levine (1999) and Leuz, Nanda and Wysocki (2003). A country's wealth potentially influences a government's decision to adopt a new legislation, as an effective legal infrastructure is costly to create and maintain (Leuz et al., 2003). For the GRI variable, sustainability certificate was used as an instrument variable. Literature has demonstrated a close connection between the GRI standard and other well-known ISO standards (Albareda, 2013; Brown et al., 2009). It is expected that companies adopting GRI standard are more likely to obtain other sustainability certificates, and vice versa. This instrument variable is measured as a dummy variable in which the value of 1 is allocated to companies with at least one sustainability certificate such as ISO 14001, ISO 9001, ISO/IEC17025, and 0 otherwise. Finally, we used the presence of sustainability committee as an instrument variable for the association variable (SASS). The presence of a sustainability committee at board level is demonstrative of a firm's acknowledgement of stakeholders (Ullman, 1985) and its intention to uphold its legitimacy in relation to social and environmental reputation (Rankin, Windsor \& Wahyuni, 2011). Such corporations are more likely to join sustainability-related associations to develop their practices. We used a dummy variable for this instrument in which the value of 1 is awarded to companies with a sustainability committee and 0 otherwise. The IV regression results are presented in table 10. Despite some minor differences in terms of coefficients and significant levels, the direction of coefficients and the significant variables remain largely the same, except for the case of MAS where the variable is no longer significant in the IV robustness test. The finding for this variable, therefore, should be interpreted with care. Overall, the results of this robustness test indicate that our findings are relatively robust and not largely affected by endogeneity.

\section{INSERT TABLE 10 ABOUT HERE}

\section{DISCUSSION}

At the very outset of our paper we argued that there is a lack of extant research related to SD from a non-western perspective. We also asserted that there was lack of understanding of how national institutional influences could differ between countries and how such influences could engender SD practices of companies operating within a specific region. 
Our findings emphasise key commonalities across the six countries, in relation to SD. The majority of firms across all six countries disclosed more about their community involvement and human resource (HR) practices than on their environmental, consumer-related and product-related sustainability practices (See Table 4). This common pattern of SD aligns with previous studies (See Djajadikerta and Trireksani, 2012; Gunawan et al., 2009; Gunawan and Hermawan, 2013; Kuasirikun and Sherer, 2004) and is also reflective of the philanthropic view of sustainability (Sharma, 2013), underpinned by inherent socio-cultural traditions in the SEA region. Furthermore, governmental tax incentives and tax exemptions (Lu, 2013), across many of these countries also aim to engender a more proactive stance towards corporate community involvement by companies (See Table 1), potentially, as a more sustainable solution to poverty alleviation (Nugroho et al., 2010; Rahman et al., 2011). The disclosure of HR practices, could be attributed to the extensive labour policies prevalent across all six countries together with the other 'soft' laws such as the United Nation Global Compact and the OECD principles (Renouard \& Ezvan, 2018). Companies in the region therefore, seem to be focused on engaging in creating shared value through their HR practices (Battaglia, et al., 2015; Holder-Webb et al., 2009; Kuasirikun \& Sherer, 2004). The lowlevel of SD in environment, consumer and product related practices, could be cognisant with limited consumer and environmental activism in region (Sharma, 2013). Thailand, however, digressed from the above commonalities, and indicated higher level of diversity in their SD with equitable disclosure across all of the sub-categories (See Table 4), potentially reflective of the country's substantive laws addressing a wider range of stakeholder issues as indicated in Table 1.

Other than commonalities in the 'levels' of SD, the findings of this study, provide much needed insights related to specific institutional pressures which could engender SD. In this regard, from a holistic perspective our findings indicate that companies operating in similar national institutional systems show similar SD patterns. More specifically, our data indicates SD across the six countries is influenced by mandated regulations (i.e. regulative influences), cultural influences (i.e. cognitive influences) and global standards for SD (i.e. normative influences).

In contrast to SD studies conducted in Western country contexts, which indicate minimal influences of mandated regulations upon SD (See Kuhn et al., 2014; Larrinaga et al., 2002; Peters \& Romi, 2013), our findings show that the strongest driver for SD in the SEA region, is in fact the presence of mandated regulation for SD, supportive of scholars who have argued for its effectiveness in influencing pro-active management SD (Ioannou \& Serafeim, 2014; Overland, 2007). Furthermore 
and in contrast to extant research (See Adelopo et al., 2012, 2013; Frias-Aceituno et al., 2013), we also found the legal system of the country does not influence SD significantly within the SEA region. Thus, countries with dissimilar legal systems (representative of different legal origins) had similar SD levels. As such, in regions consisting of developing countries with progressive states of institutional developments, such as in the SEA region, not all components of a country's regulative element can act as determinants for SD.

We also found that cultural norms and expectations, influenced SD quite strongly, with firms operating in countries with similar cultural traits and systems, demonstrating homogeneous forms of behaviour in relation to SD. More specifically, we found that firms operating in countries with Feminist cultural dimension, engaged more in SD, as well as those from countries with higher level of Uncertainty Avoidance. Collectively, this result indicates the prevalence of companies operating in the SEA region to adhere to societal and stakeholder expectations as mechanism for reducing operational uncertainties (Adelopo et al., 2013) and improve societal welfare by doing "what is right'. In summary, our findings show strong evidence of the influence the cultural cognitive dimension as a key institutional influence for SD, and its role in shaping firms' behaviour through social pressures for conformity based on shared beliefs and taken for granted actions (Shnayder et al., 2016).

In line with other previous studies, we found that GRI, as an international standard, was effective in influencing firms' SD (See Barkemeyer et al., 2015; Comyns, 2016), thereby reaffirming the effectiveness of GRI as a key normative influence upon SD from a global perspective (Barkemeyer et al., 2015; Brown et al., 2009; Etzion \& Ferraro, 2010; Levy et al., 2010). In contrast to the positive impact of GRI on SD, we found that membership of country-level business associations was found to have no influence on firm-level SD. Our finding is aligned with observations from previous studies (See Ali et al., 2017; Tang et al., 2014) that professional associations in some regions, may be ineffective in promoting SD due to a lack of implementation and monitoring systems (Nurunnabi, 2015).

\section{CONCLUSION}

Based upon the above discussions related to firm-level SD across six countries operating in the SEA region, we examine three key contributions derived from our study. 
First, our study presents insights into commonalities and nuanced differences in the institutional contexts across six countries in SEA region, responding to calls for more comparative SD studies from non-western perspectives (Arena, Liong \& Vourvachis, 2018; Patten \& Shin, 2019; Tilt, 2016; Williams \& Aguilera, 2008). Thus, our findings could enable an expansive understanding of SD within the SEA region, and its institutional environment, potentially opening up opportunities for more comparative cross-national research from a multi-region perspective. Second, while we found that all of these institutional pressures (i.e. regulative, cultural-cognitive and normative) propagated SD, our findings specifically supported the influential effects of regulative and cultural cognitive pressures on companies and managers in their disclosure decision than normative pressures, reaffirming previous scholars' arguments that not all institutional factors impose the same pressures upon organisational practices (Mainardes et al., 2011). It also emphasises the importance of examining the nature of institutional pressures to understand how their configurations of in different countries could shape non-market practise such as SD (Jamali \& Carroll, 2017; Hartmann \& Uhlenbruck, 2015). Finally and in line with the above argument, our study measures each of the three institutional influences as denoted by Scott (1995); regulative, normative and cultural-cognitive, and thereby addressed criticisms in extant studies of focusing on a single institutional influence (see Adelopo and Moure, 2010; Cahan et al., 2016; Gallen \& Peraita, 2018; Kilic, Iuar \& Karaman, 2019), as well as the lack of theoretical justification in identifying institutional influences derived upon founded upon neo-institutional theory (Martinez-Ferrero \& Garcia-Sanchez, 2017). By adopting Scott's (2008b) arguments to consider all the three institutional influences in tandem to generate a comprehensive understanding of institutions which could engender SD, we provide an alternative framework to identify external influencing factors, and overcomes the narrow operationalization of institutions (Abdelnour, Hasselbladh \& Kallinikos, 2017).

The nature of this study, however, does present certain limitations. First, as the subject of the sample are large listed companies in the stock exchanges, the findings provide limited interpretation of other types of companies. Future studies might consider conducting research on Small and Medium Enterprises (SMEs) to allow a better interpretation of SD in the countries. Second, our study was limited to the data obtained from the annual reports of the companies in our sample. By considering other SD communication channels, future studies might provide deeper insights, about the nature and scope of corporate SD in the region. Finally, while this study provides 
interesting findings on SD practice in SEA region, we do not focus on differentiating between developing and developed contexts. Nevertheless, according to Jamali and Carroll (2017), our understanding of how institutional configurations shape these practices across developed and developing countries remains limited. Future researchers could respond to this existing gap by adopting a comparative approach to provide a profound understanding of the commonalities and differences of institutional environment and its effect on SD practice across developing and developed countries.

In conclusion, SD practices in the SEA region leaves much room for further improvement. Through our study, we encourage policymakers and regulators from the investigated countries to learn from the experiences of each other to better promote and develop sustainability practices within their national context. Regulatory processes should be oriented towards mandating some key aspects of sustainability, such as SD, to alter firms' behaviour through coercive pressures to protect stakeholder interests. 


\section{APPENDIX}

\section{APPENDIX 1: List of sustainability-related associations}

\begin{tabular}{|c|c|c|}
\hline Country & Association's name & Description \\
\hline Indonesia & $\begin{array}{l}\text { Global Compact Network } \\
\text { Indonesia }\end{array}$ & $\begin{array}{l}\text { Indonesia Global Compact Network (IGCN) was established in } 2006 \\
\text { in Jakarta with the chief aim to promote United Nations Global } \\
\text { Compact Principles in Indonesia. The network started with a mutual } \\
\text { commitment of twenty-two companies and organisations. } \\
\text { URL: http://indonesiagcn.org/ }\end{array}$ \\
\hline Malaysia & $\begin{array}{l}\text { Business Council for } \\
\text { Sustainability and Responsibility } \\
\text { Malaysia }\end{array}$ & $\begin{array}{l}\text { The Business Council for Sustainability and Responsibility Malaysia } \\
\text { (BCSRM) is a national organisation established in } 1992 \text { by business } \\
\text { leaders from a diverse set of industries to promote responsible and } \\
\text { sustainable practices. The BCSRM is also a regional partner of the } \\
\text { World Business Council for Sustainable Development (WBCSD). } \\
\text { The organisation's key mission is to act as the government's } \\
\text { advocate council for sustainability in Malaysia. } \\
\text { URL: http://www.bcsrmalaysia.org }\end{array}$ \\
\hline Philippines & $\begin{array}{l}\text { The Philippine Business for Social } \\
\text { Progress }\end{array}$ & $\begin{array}{l}\text { The Philippine Business for Social Progress (PBSP) was established } \\
\text { in } 1970 \text { as one of the first associations of its kind in Southeast Asia. } \\
\text { PBSP is the largest business-led social development NGO in } \\
\text { Philippines and advocates sustainable development and poverty } \\
\text { reduction. The organisation partners with a range of companies that } \\
\text { want to add strategic value to their CSR programs. } \\
\text { PBSP has more than } 267 \text { large, small and medium enterprises as } \\
\text { members that participate in social development programs focusing } \\
\text { on health, education, the environment and Livelihood and enterprise } \\
\text { development (HEEL). The organisation has been the main advocator } \\
\text { for stronger corporate citizenship. } \\
\text { URL: http://www.pbsp.org.ph }\end{array}$ \\
\hline Singapore & Singapore Compact for CSR & $\begin{array}{l}\text { The Singapore Compact for CSR was established in } 2005 \text { as part of } \\
\text { the United Nations Global Compact (UNGC) network. The network } \\
\text { encourages and supports companies in aligning their operations and } \\
\text { strategies with UNGC's principles. The main role of the network is } \\
\text { to work with diverse stakeholders and promote responsible business } \\
\text { practices. } \\
\text { URL: } \text { http://www.csrsingapore.org }\end{array}$ \\
\hline Thailand & $\begin{array}{l}\text { Thailand Business Council for } \\
\text { Sustainable Development }\end{array}$ & $\begin{array}{l}\text { The Thailand Business Council for Sustainable Development } \\
\text { (TBCSD) was founded in } 1993 \text { by a former Prime Minister of } \\
\text { Thailand with the main objective of promoting environmental } \\
\text { awareness in the business sector under the concept of sustainable } \\
\text { development. } \\
\text { URL: http://www.tei.or.th/tbcsd/ }\end{array}$ \\
\hline Vietnam & $\begin{array}{lll}\text { Global } & \text { Compact } & \text { Network } \\
\text { Vietnam } & & \end{array}$ & $\begin{array}{l}\text { The Global Compact Network Vietnam (GCNV) was established in } \\
2007 \text { with the partnership between Vietnam Chamber of Commerce } \\
\text { and Industry (VCCI) and the United Nations in Vietnam (UN). The } \\
\text { network goal is to become the national CSR centre of excellence, } \\
\text { promoting sustainable businesses. } \\
\text { URL: http://www.globalcompactvietnam.org/ }\end{array}$ \\
\hline
\end{tabular}




\section{APPENDIX 2: Sustainability disclosure checklist}

\section{ENVIRONMENTAL DISCLOSURE}

- Environmental policies or expression of environmental concerns

- Certified environmental management systems and audit

- Pollution (air, water, noise, visual and wastes) from business conduct

- Pollution/ effort to reduce pollution created from the use of company's products

- Prevention and/or repair of environmental damage

- Conservation of natural resources and recycling activities

- Sustainable development/ management

- Designing or contributing to develop facilities harmonious with the environment

- Energy conservation in operations

- Sustainable products or services

- Discussion of environmental laws and regulations

\section{HUMAN RESOURCES DISCLOSURE}

- Employee Health and Safety

- Recruitment policy for minorities and/or women

- Human resources profile

- Employment remuneration

- Share options for employees

- Employee assistance/ benefits

- Employee training

- Employee morale

- Relationship with trade unions and/or workers

\section{PRODUCTS AND CONSUMER DISCLOSURE}

- Product safety (information on safety, safety standards)

- Product quality (prizes/ awards/ certificates)

- Disclosing of consumer safety practices (protecting consumers' right and safety)

- Consumer satisfaction and feedback

- Accommodating disabled, aged, and difficult-to-reach consumers

\section{COMMUNITY INVOLVEMENT DISCLOSURE}

- Charitable donations and activities

- Support for education

- Support for arts and culture

- Support for public health

- Sponsoring sporting or recreational projects 


\section{REFERENCES}

Abdelnour, S., Hasselbladh, H., \& Kallinikos, J. (2017). Agency and institutions in organization studies. Organization Studies, 38(12), 1775-1792.

Abd-Mutalib, H., Jamil, C. M., \& Wan-Hussin, W. N. (2014). The availability, extent and quality of sustainability reporting by Malaysian listed firms: Subsequent to mandatory disclosure. Asian Journal of Finance \& Accounting, 6(2), 239-257.

Adams, C. A., \& Frost, G. R. (2007). Managing social and environmental performance: do companies have adequate information? Australian Accounting Review, 17(3), 2.

Adelopo, I. A., \& Moure, R. C. (2010). Time and Country Specific Institutional Effects on Corporate Social Disclosure by Financial Institutions: Evidence from Fourteen European Countries. Available at SSRN 1719096.

Adelopo, I., Cea Moure, R., Vargas Preciado, L., \& Obalola, M. (2012). Determinants of webaccessibility of corporate social responsibility communications. Journal of Global Responsibility, 3(2), 235-247.

Adelopo, I., Moure, R. C., \& Obalola, M. (2013). On the effects of legal and cultural institutions on corporate social disclosures by banks. Leicester: De Montfort University.

Aguilera, R. V., Rupp, D. E., Williams, C. A., \& Ganapathi, J. (2007). Putting the S back in corporate social responsibility: A multilevel theory of social change in organizations. Academy of management review, 32(3), 836-863.

Aguinis, H., \& Glavas, A. (2012). What We Know and Don't Know About Corporate Social Responsibility: A Review and Research Agenda. Journal of Management, 38(4), 932-968.

Albareda, L. (2013). CSR governance innovation: Standard competition-collaboration dynamic. Corporate Governance, 13(5), 551-568.

Al-Bassam, W. M., Ntim, C. G., Opong, K. K., \& Downs, Y. (2018). Corporate boards and ownership structure as antecedents of corporate governance disclosure in Saudi Arabian publicly listed corporations. Business \& Society, 57(2), 335-377.

Ali, W., Frynas, J. G., \& Mahmood, Z. (2017). Determinants of Corporate Social Responsibility (CSR) Disclosure in Developed and Developing Countries: A Literature Review. Corporate Social Responsibility and Environmental Management.

Amor-Esteban, V., García-Sánchez, I.-M., \& Galindo-Villardón, M.-P. (2017). Analysing the Effect of Legal System on Corporate Social Responsibility (CSR) at the Country Level, from a Multivariate Perspective. Social Indicators Research, 1-18.

Amran, A., \& Devi, S. S. (2008). The impact of government and foreign affiliate influence on corporate social reporting: The case of Malaysia. Managerial Auditing Journal, 23(4), 386-404.

Amran, A., \& Haniffa, R. (2011). Evidence in development of sustainability reporting: a case of a developing country. Business Strategy and the Environment, 20(3), 141-156.

Amran, A., Ooi, S. K., Wong, C. Y., \& Hashim, F. (2016). Business Strategy for Climate Change: An ASEAN Perspective. Corporate Social Responsibility and Environmental Management, 23(4), 213-227.

Anas, A., Rashid, H. M. A., \& Annuar, H. A. (2015). The effect of award on CSR disclosures in annual reports of Malaysian PLCs. Social Responsibility Journal, 11(4), 831-852.

Arena, C., Liong, R., \& Vourvachis, P. (2018). Carrot or stick: CSR disclosures by Southeast Asian companies. Sustainability Accounting, Management and Policy Journal, 9(4), 422454.

Asia-Pacific Economic Cooperation [APEC] (2005). Corporate Social Responsibility in the APEC region: Current Status and Implications. Retrieved from http://publications.apec.org/publication-detail.php?pub_id=341

Barakat, F. S. Q., Pérez, M. V. L., \& Ariza, L. R. (2015). Corporate social responsibility 
disclosure (CSRD) determinants of listed companies in Palestine (PXE) and Jordan (ASE). Review of Managerial Science, 9(4), 681-702.

Barkemeyer, R., Preuss, L., \& Lee, L. (2015). On the effectiveness of private transnational governance regimes - Evaluating corporate sustainability reporting according to the Global Reporting Initiative. Journal of World Business, 50(2), 312-325.

Battaglia, M., Bianchi, L., Frey, M., \& Passetti, E. (2015). Sustainability reporting and corporate identity: Action research evidence in an Italian retailing cooperative. Business Ethics: A European Review, 24(1), 52-72.

Baughn, C. C., (Dusty) Bodie, N. L., \& McIntosh, J. C. (2007). Corporate social and environmental responsibility in Asian countries and other geographical regions. Corporate Social Responsibility and Environmental Management, 14(4), 189-205.

Belal, A. R., \& Momin, M. (2009). Corporate social reporting (CSR) in emerging economies: a review and future direction. Research in accounting in emerging economies, 9, 119-143.

Belal, A. R., Cooper, S. M., \& Roberts, R. W. (2013). Vulnerable and exploitable: The need for organisational accountability and transparency in emerging and less developed economies. Accounting Forum, 37(2), 81-91.

Bowrin, A. R. (2013). Corporate social and environmental reporting in the Caribbean. Social Responsibility Journal, 9(2), 259-280.

Brammer, S., Jackson, G., \& Matten, D. (2012). Corporate Social Responsibility and institutional theory: new perspectives on private governance. Socio-Economic Review, 10(1), 3-28.

Branco, M. C., \& Rodrigues, L. L. (2008). Factors Influencing Social Responsibility Disclosure by Portuguese Companies. Journal of Business Ethics, 83(4), 685-701.

Brown, H. S., de Jong, M., \& Levy, D. L. (2009). Building institutions based on information disclosure: lessons from GRI's sustainability reporting. Journal of Cleaner Production, 17(6), 571-580.

Bruton, G. D., Ahlstrom, D., \& Li, H. L. (2010). Institutional theory and entrepreneurship: where are we now and where do we need to move in the future? Entrepreneurship theory and practice, 34(3), 421-440.

Buhr, N., \& Freedman, M. (2001). Culture, Institutional Factors and Differences in Environmental Disclosure Between Canada and the United States. Critical Perspectives on Accounting, 12(3), 293-322.

Cahan, S. F., De Villiers, C., Jeter, D. C., Naiker, V., \& Van Staden, C. J. (2016). Are CSR Disclosures Value Relevant? Cross-Country Evidence. European Accounting Review, 25(3), 579-611.

Campbell, J. L. (2007). Why Would Corporations Behave in Socially Responsible Ways? An Institutional Theory of Corporate Social Responsibility. The Academy of Management Review, 32(3), 946-967.

Central Intelligence Agency [C.I.A]. (n.d.). Legal system. Retrieved from https://www.cia.gov/library/publications/the-world-factbook/fields/2100.html

Chakroun, R., \& Matoussi, H. (2012). Determinants of the Extent of Voluntary Disclosure in the Annual Reports of the Tunisian Firms. Accounting and Management Information Systems, 11(3), 335.

Chan, M. C., Watson, J., \& Woodliff, D. (2014). Corporate Governance Quality and CSR Disclosures. Journal of Business Ethics, 125(1), 59-73.

Chapple, W., \& Moon, J. (2005). Corporate Social Responsibility (CSR) in Asia: A SevenCountry Study of CSR Web Site Reporting. Business \& Society, 44(4), 415-441.

Christmann, P., \& Taylor, G. (2006). Firm Self-Regulation through International Certifiable Standards: Determinants of Symbolic versus Substantive Implementation. Journal of International Business Studies, 37(6), 863-878. 
Clarke, J., \& Gibson-Sweet, M. (1999). The use of corporate social disclosures in the management of reputation and legitimacy: A cross sectoral analysis of UK top 100 companies. Business Ethics, A European Review, 8(1), 5-13.

Comyns, B. (2016). Determinants of GHG Reporting: An Analysis of Global Oil and Gas Companies. Journal of Business Ethics, 136(2), 349-369.

de Villiers, C., \& Alexander, D. (2014). The institutionalisation of corporate social responsibility reporting. The British Accounting Review, 46(2), 198-212.

Domínguez, A.A.M. (2012). Company characteristics and human resource disclosure in Spain. Social Responsibility Journal, 8(1), 4-20.

Eccles, R. G., Ioannou, I., \& Serafeim, G. (2014). The Impact of Corporate Sustainability on Organizational Processes and Performance. Management Science, 60(11), 2835-2857.

El-Halaby, S., \& Hussainey, K. (2015). The determinants of social accountability disclosure: Evidence from islamic banks around the world. International Journal of Business, 20(3), 202-223.

Elmagrhi, M. H. A. (2016). Corporate Governance, Voluntary Compliance, Corporate Performance and Executive Pay: Evidence from the UK. University of Huddersfield,

Esa, E., \& Ghazali, N. M. (2012). Corporate social responsibility and corporate governance in Malaysian government-linked companies. Corporate Governance: The international journal of business in society, 12(3), 292-305.

Etzion, D., \& Ferraro, F. (2010). The Role of Analogy in the Institutionalization of Sustainability Reporting. Organization Science, 21(5), 1092-1107.

Fassin, Y., Werner, A., Rossem, A. V., Signori, S., Garriga, E., Heidi von Weltzien, H., \& Schlierer, H.-J. (2015). CSR and Related Terms in SME Owner-Managers' Mental Models in Six European Countries: National Context Matters. Journal of Business Ethics, 128(2), 433-456.

Fifka, M. S., \& Drabble, M. (2012). Focus and Standardization of Sustainability Reporting A Comparative Study of the United Kingdom and Finland. Business Strategy and the Environment, 21(7), 455-474.

Frias-Aceituno, J. V., Rodriguez-Ariza, L., \& Garcia-Sanchez, I. M. (2013a). The Role of the Board in the Dissemination of Integrated Corporate Social Reporting. Corporate Social Responsibility and Environmental Management, 20(4), 219-233.

Frías-Aceituno, J. V., Rodríguez-Ariza, L., \& García-Sánchez, I. M. (2013b). Is integrated reporting determined by a country's legal system? An exploratory study. Journal of Cleaner Production, 44, 45-55.

Galaskiewicz, J. (1991). Making corporate actors accountable: Institution-building in Minneapolis-St. Paul. The new institutionalism in organizational analysis, 293, 310.

Gallego-Alvarez, I., Ortas, E., Vicente-Villardón, J. L., \& Álvarez Etxeberria, I. (2017). Institutional Constraints, Stakeholder Pressure and Corporate Environmental Reporting Policies: Forces Influencing Corporate Environmental Reporting Policies. Business Strategy and the Environment, 26(6), 807-825.

Gallén, M. L., \& Peraita, C. (2018). The effects of national culture on corporate social responsibility disclosure: a cross-country comparison. Applied Economics, 50(27), 29672979.

Gallén, M. L., \& Peraita, C. (2018). The effects of national culture on corporate social responsibility disclosure: A cross-country comparison. Applied Economics, 50(27), 29672979.

Garcia-Sanchez, I.-M., Cuadrado-Ballesteros, B., \& Frias-Aceituno, J.-V. (2016). Impact of the Institutional Macro Context on the Voluntary Disclosure of CSR Information. Long Range Planning, 49(1), 15-35.

García-Sánchez, I.-M., Rodríguez-Ariza, L., \& Frías-Aceituno, J.-V. (2013). The cultural 
system and integrated reporting. International Business Review, 22(5), 828-838.

Gauthier, J. (2013). Institutional Theory and Corporate Sustainability: Determinant Versus Interactive Approaches. Organization Management Journal, 10(2), 86-96.

Ghazali, N. A. M. (2007). Ownership structure and corporate social responsibility disclosure: some Malaysian evidence. Corporate Governance: The international journal of business in society, 7(3), 251-266.

Gond, J. P., \& Moon, J. (2011). Corporate social responsibility in retrospect and prospect: Exploring the life-cycle of an essentially contested concept. ICCSR Research Paper Series, 59, 1-40.

Gray, R. (2002). The social accounting project and Accounting Organizations and Society Privileging engagement, imaginings, new accountings and pragmatism over critique? Accounting, Organizations and Society, 27(7), 687-708.

Gray, R., Kouhy, R., \& Lavers, S. (1995). Corporate social and environmental reporting: A review of the literature and a longitudinal study of UK disclosure. Accounting, Auditing \& Accountability Journal, 8(2), 47.

Gray, S. J. (1988). Towards a Theory of Cultural Influence on the Development of Accounting Systems Internationally. Abacus, 24(1), 1-15.

Hahn, R., \& Kühnen, M. (2013). Determinants of sustainability reporting: a review of results, trends, theory, and opportunities in an expanding field of research. Journal of Cleaner Production, 59, 5-21.

Haji, A. A. (2013). Corporate social responsibility disclosures over time: evidence from Malaysia. Managerial Auditing Journal, 28(7), 647-676.

Hartmann, J., \& Uhlenbruck, K. (2015). National institutional antecedents to corporate environmental performance. Journal of World Business, 50(4), 729-741.

Hermawan, A., \& Gunardi, A. (2019). Motivation for disclosure of corporate social responsibility: evidence from banking industry in Indonesia. Entrepreneurship and Sustainability Issues, 6(3), 1297-1306.

Herrera, M. E. B., Roman, F., \& Alarilla, M. (2011). Corporate social responsibility in Southeast Asia: An eight country analysis. Manila: Ramon V. del Rosario Sr. Centre for Corporate Social Responsibility, Asian Institute of Management.

Hieu, P. D. (2011). Corporate social responsibility: A study on awareness of managers and consumers in Vietnam. Journal of Accounting and Taxation, 3(8), 158.

Hoffman, A. J. (1999). Institutional Evolution and Change: Environmentalism and the U.S. Chemical Industry. The Academy of Management Journal, 42(4), 351-371.

Hofstede, G. (2001). Culture's consequences: Comparing values, behaviors, institutions, and organizations across nations (2nd ed.). Thousand Oaks, London: SAGE.

Holder-Webb, L., Cohen, J. R., Nath, L., \& Wood, D. (2009). The Supply of Corporate Social Responsibility Disclosures among U.S. Firms. Journal of Business Ethics, 84(4), 497-527.

Hope, O. K. (2003). Firm-level disclosures and the relative roles of culture and legal origin. Journal of International Financial Management \& Accounting, 14(3), 218-248.

Hu, M., \& Loh, L. (2018). Board governance and sustainability disclosure: A cross-sectional study of Singapore-listed companies. Sustainability (Switzerland), 10(7), 2578.

Hummel, K., \& Schlick, C. (2016). The relationship between sustainability performance and sustainability disclosure - reconciling voluntary disclosure theory and legitimacy theory. Journal of Accounting and Public Policy, 35(5), 455-476.

Ioannou, I., \& Serafeim, G. (2012). What drives corporate social performance? The role of nation-level institutions. Journal of International Business Studies, 43(9), 834-864.

Ioannou, I., \& Serafeim, G. (2014). The consequences of mandatory corporate sustainability reporting: evidence from four countries. Harvard Business School Research Working Paper (11-100). 
Irvine, H. (2008). The global institutionalization of financial reporting: The case of the United Arab Emirates. Accounting Forum, 32(2), 125-142.

Islam, M. A., Jain, A., \& Thomson, D. (2016). Does the global reporting initiative influence sustainability disclosures in Asia-Pacific banks? Australasian Journal of Environmental Management, 23(3), 298-313.

Jackson, G., \& Apostolakou, A. (2010). Corporate social responsibility in Western Europe: an institutional mirror or substitute? Journal of Business Ethics, 94(3), 371-394.

Jamali, D., \& Carroll, A. (2017). Capturing advances in CSR: Developed versus developing country perspectives. Business Ethics: A European Review, 26(4), 321-325.

Jamali, D., Karam, C., Yin, J., \& Soundararajan, V. (2017). CSR logics in developing countries: Translation, adaptation and stalled development. Journal of World Business, 52(3), 343-359.

Janggu, T., Darus, F., Zain, M. M., \& Sawani, Y. (2014). Does Good Corporate Governance Lead to Better Sustainability Reporting? An Analysis Using Structural Equation Modeling. Procedia - Social and Behavioral Sciences, 145, 138-145.

Jizi, M. I., Salama, A., Dixon, R., \& Stratling, R. (2014). Corporate Governance and Corporate Social Responsibility Disclosure: Evidence from the US Banking Sector. Journal of Business Ethics, 125(4), 601-615.

Kang, K. H., Lee, S., \& Yoo, C. (2016). The effect of national culture on corporate social responsibility in the hospitality industry. International Journal of Contemporary Hospitality Management, 28(8), 1728-1758.

Khan, A., Muttakin, M. B., \& Siddiqui, J. (2013). Corporate Governance and Corporate Social Responsibility Disclosures: Evidence from an Emerging Economy. Journal of Business Ethics, 114(2), 207-223.

Khan, M. H.U.Z. (2010). The effect of corporate governance elements on corporate social responsibility (CSR) reporting: Empirical evidence from private commercial banks of Bangladesh. International Journal of Law and Management, 52(2), 82-82.

Khan, Z., Lew, Y. K., \& Park, B. I. (2015). Institutional legitimacy and norms-based CSR marketing practices: Insights from MNCs operating in a developing economy. International Marketing Review, 32(5), 463-491.

Kılıç, M., Uyar, A., \& Karaman, A. S. (2019). What impacts sustainability reporting in the global aviation industry? An institutional perspective. Transport Policy, 79, 54-65.

Kim, C. H., Amaeshi, K., Harris, S., \& Suh, C.J. (2013). CSR and the national institutional context: The case of South Korea. Journal of Business Research, 66(12), 2581-2591.

Kim, R. C., \& Moon, J. (2015). Dynamics of corporate social responsibility in Asia: Knowledge and norms. Asian Business and Management, 14(5), 349-382.

Kostova, T., \& Roth, K. (2002). Adoption of an Organizational Practice by Subsidiaries of Multinational Corporations: Institutional and Relational Effects. The Academy of Management Journal, 45(1), 215-233.

Kouwenberg, R., Salomons, R., \& Thontirawong, P. (2014). Corporate governance and stock returns in Asia. Quantitative Finance, 14(6), 965-976.

Kuasirikun, N., \& Sherer, M. (2004). Corporate social accounting disclosure in Thailand. Accounting, Auditing \& Accountability Journal, 17(4), 629.

Kühn, A. L., Stiglbauer, M., \& Heel, J. (2014). Does mandatory CSR reporting lead to higher CSR transparency? The case of France. Corporate Ownership and Control, 11(2), 29-45.

La Porta, R., Lopez-de-Silanes, F., \& Shleifer, A. (2008). The Economic Consequences of Legal Origins. Journal of Economic Literature, 46(2), 285-332.

Larrinaga, C., Carrasco, F., Correa, C., Llena, F., \& Moneva, J. (2002). Accountability and accounting regulation: The case of the Spanish environmental disclosure standard. European Accounting Review, 11(4), 723-740. 
Lee, M. H., Mak, K. A., \& Pang, A. (2012). Bridging the gap: An exploratory study of corporate social responsibility among SMEs in Singapore. Journal of Public Relations Research, 24(4), 299-317.

Leuz, C., Nanda, D., \& Wysocki, P. D. (2003). Earnings management and investor protection: An international comparison. Journal of Financial Economics, 69(3), 505-527.

Levine, R. (1999). Law, finance, and economic growth. Journal of Financial Intermediation, 8(1-2), 8-35.

Levy, D. L., Brown, H., \& de Jong, M. (2010). The Contested Politics of Corporate Governance: The Case of the Global Reporting Initiative. Business \& Society, 49(1), 88115.

Li, S., Fetscherin, M., Alon, I., Lattemann, C., \& Yeh, K. (2010). Corporate Social Responsibility in Emerging Markets: The Importance of the Governance Environment. MIR: Management International Review, 50(5), 635-654.

Lu, J.Y. (2013). An Exploratory Study on Corporate Social Responsibility (CSR) in Malaysia: National and Organisation-Centric Perspectives (PhD thesis). University of Canterbury.

Mainardes, E., Alves, H., \& Raposo, M. (2011). Stakeholder theory: issues to resolve. Management Decision, 49(2), 226-252.

Maon, F., Swaen, V., \& Lindgreen, A. (2017). One Vision, Different Paths: An Investigation of Corporate Social Responsibility Initiatives in Europe. Journal of Business Ethics, 143(2), 405-422.

Marquis, C., \& Toffel, M. W. (2012). When do firms greenwash?: Corporate visibility, civil society scrutiny, and environmental disclosure. Boston, MA: Harvard Business School.

Marrewijk, M. v., \& Werre, M. (2003). Multiple Levels of Corporate Sustainability. Journal of Business Ethics, 44(2/3), 107-119.

Martin, R. L. (2002). The virtue matrix: Calculating the return on corporate responsibility. Harvard business review, 80(3), 68-75.

Martínez-Ferrero, J., \& García-Sánchez, I.-M. (2017). Coercive, normative and mimetic isomorphism as determinants of the voluntary assurance of sustainability reports. International Business Review, 26(1), 102-118.

Matten, D., \& Moon, J. (2008). "implicit" and "explicit" CSR: A conceptual framework for a comparative understanding of corporate social responsibility. The Academy of Management Review, 33(2), 404-424.

Michelon, G. (2011). Sustainability Disclosure and Reputation: A Comparative Study. Corporate Reputation Review, 14(2), 79-96.

Mio, C., \& Venturelli, A. (2013). Non-financial Information About Sustainable Development and Environmental Policy in the Annual Reports of Listed Companies: Evidence from Italy and the UK. Corporate Social Responsibility and Environmental Management, 20(6), 340-358.

Miska, C., Szőcs, I., \& Schiffinger, M. (2018). Culture's effects on corporate sustainability practices: A multi-domain and multi-level view. Journal of World Business, 53(2), 263 279.

Muthuri, J. N., \& Gilbert, V. (2011). An Institutional Analysis of Corporate Social Responsibility in Kenya. Journal of Business Ethics, 98(3), 467-483.

Mzembe, A. N., Melissen, F., \& Novakovic, Y. (2019). Greening the hospitality industry in the developing world: Analysis of the drivers and barriers. Business Ethics: A European Review, 28(3), 335-348.

Naser, K., \& Hassan, Y. (2013). Determinants of corporate social responsibility reporting: Evidence from an emerging economy. Journal of Contemporary Issues in Business Research, 2(3), 56-74.

Nobanee, H., \& Ellili, N. (2016). Corporate sustainability disclosure in annual reports: 
Evidence from UAE banks: Islamic versus conventional. Renewable and Sustainable Energy Reviews, 55, 1336-1341.

North, D. C. (1990). Institutions, institutional change and economic performance. Cambridge: Cambridge University Press.

Ntim, C. G., \& Soobaroyen, T. (2013). Corporate Governance and Performance in Socially Responsible Corporations: New Empirical Insights from a Neo-Institutional Framework. Corporate Governance: An International Review, 21(5), 468-494.

Ntim, C. G., Opong, K. K., \& Danbolt, J. (2012). The Relative Value Relevance of Shareholder versus Stakeholder Corporate Governance Disclosure Policy Reforms in South Africa. Corporate Governance: An International Review, 20(1), 84-105.

Nurunnabi, M. (2015). Tensions between politico-institutional factors and accounting regulation in a developing economy: insights from institutional theory. Business Ethics: A European Review, 24(4), 398-424.

O'Connor, A., Parcha, J. M., \& Tulibaski, K. L. G. (2017). The institutionalization of corporate social responsibility communication: An intra-industry comparison of MNCs' and SMEs' CSR reports. Management Communication Quarterly, 31(4), 503-532.

Othman, S., Darus, F., \& Arshad, R. (2011). The influence of coercive isomorphism on corporate social responsibility reporting and reputation. Social Responsibility Journal, $7(1), 119-135$.

Overland, J. (2007). Corporate Social Responsibility in Context: The Case for Compulsory Sustainability Disclosure for Listed Public Companies in Australia? Macquarie Journal of International and Comparative Environmental Law, 4(2), 1-22.

Palmer, D., Biggart , N., \& Dick, B. (2013; 2008). Is the New Institutionalism a Theory? In G. Royston, Christine, O., Roy, S., \& Kerstin, S. (Ed.), The SAGE handbook of organizational institutionalism. Los Angeles: SAGE.

Parker, L. D. (1986). Polemical themes in social accounting: a scenario for standard setting. Advances in Public Interest Accounting, 1, 67-93.

Parsa, S., \& Kouhy, R. (2008). Social Reporting by Companies Listed on the Alternative Investment Market. Journal of Business Ethics, 79(3), 345-360.

Patten, D. M., \& Shin, H. (2019). Sustainability Accounting, Management and Policy Journal's contributions to corporate social responsibility disclosure research. Sustainability Accounting, Management and Policy Journal, 10(1), 26-40.

Pedersen, E. R. G., Neergaard, P., Pedersen, J. T., \& Gwozdz, W. (2013). Conformance and deviance: company responses to institutional pressures for corporate social responsibility reporting. Business Strategy and the Environment, 22(6), 357-373.

Peng, M. W., \& Heath, P. S. (1996). The growth of the firm in planned economies in transition: Institutions, organizations, and strategic choice. Academy of management review, 21(2), 492-528.

Peng, M. W., Denis, Y. L. W., \& Jiang, Y. (2008). An Institution-Based View of International Business Strategy: A Focus on Emerging Economies. Journal of International Business Studies, 39(5), 920-936.

Peng, M. W., Sun, S. L., Pinkham, B., \& Chen, H. (2009). The institution-based view as a third leg for a strategy tripod. Academy of Management Perspectives, 23(3), 63-81.

Perez-Batres, L. A., Miller, V. V., \& Pisani, M. J. (2010). CSR, Sustainability and the Meaning of Global Reporting for Latin American Corporations. Journal of Business Ethics, 91(S2), 193-209.

Peters, G. F., \& Romi, A. M. (2013). Discretionary compliance with mandatory environmental disclosures: Evidence from SEC filings. Journal of Accounting and Public Policy, 32(4), 213-236.

Rahman, N. H. W. A., Zain, M. M., \& Al-Haj, N. H. Y. Y. (2011). CSR disclosures and its 
determinants: evidence from Malaysian government link companies. Social Responsibility Journal, 7(2), 181-201.

Rankin, M., Windsor, C., \& Wahyuni, D. (2011). An investigation of voluntary corporate greenhouse gas emissions reporting in a market governance system: Australian evidence. Accounting, Auditing \& Accountability Journal, 24(8), 1037-1070.

Rao-Nicholson, R., Khan, Z., \& Marinova, S. (2019). Balancing social and political strategies in emerging markets: Evidence from india. Business Ethics: A European Review, 28(1), 56-70.

Reimann, F., Ehrgott, M., Kaufmann, L., \& Carter, C. R. (2012). Local stakeholders and local legitimacy: MNEs' social strategies in emerging economies. Journal of International Management, 18(1), 1-17.

Renouard, C., \& Ezvan, C. (2018). Corporate social responsibility towards human development: A capabilities framework. Business Ethics: A European Review, 27(2), 144155.

Rodríguez, L. C., \& LeMaster, J. (2007). Voluntary Corporate Social Responsibility Disclosure: SEC “CSR Seal of Approval”. Business \& Society, 46(3), 370-384.

Schreck, P., \& Raithel, S. (2018). Corporate Social Performance, Firm Size, and Organizational Visibility: Distinct and Joint Effects on Voluntary Sustainability Reporting. Business \& Society, 57(4), 742-778.

Scott, W. R. (1995). Institutions and organizations (Vol. 2): Sage Thousand Oaks, CA.

Scott, W. R. (2004). Institutional Theory: Contributing to a Theoretical Research Program. In K. G. Smith \& M. Hitt, A. (Eds.), Great minds in management: The process of theory development. Oxford UK: Oxford University Press.

Scott, W. R. (2008). Institutions and organizations: Ideas and interests. Sage.

Scott, W. R. (2008a). Approaching adulthood: the maturing of institutional theory. Theory and society, 37(5), 427-442.

Scott, W. R. (2013). Institutions and organizations: Ideas, interests, and identities: Sage Publications.

Sharma, B. (2013). Contextualising CSR in Asia: Corporate Social Responsibility in Asian economies. Singapore: Lien Centre for Social Innovation.

Shnayder, L., van Rijnsoever, F. J., \& Hekkert, M. P. (2016). Motivations for Corporate Social Responsibility in the packaged food industry: an institutional and stakeholder management perspective. Journal of Cleaner Production, 122, 212-227.

Smith, J. L., Adhikari, A., \& Tondkar, R. H. (2005). Exploring differences in social disclosures internationally: A stakeholder perspective. Journal of Accounting and Public Policy, 24(2), 123-151.

Smith, J., Haniffa, R., \& Fairbrass, J. (2011). A Conceptual Framework for Investigating 'Capture' in Corporate Sustainability Reporting Assurance. Journal of Business Ethics, 99(3), 425-439.

Srinivasan, V. (2011). Business ethics in the south and South East Asia. Journal of Business Ethics, 104(1), 73-81.

Steensma, H. K., Marino, L., \& Weaver, K. M. (2000). Attitudes toward Cooperative Strategies: A Cross-Cultural Analysis of Entrepreneurs. Journal of International Business Studies, 31(4), 591-609.

Tan, E. K. B. (2013). Molding the nascent corporate social responsibility agenda in Singapore: of pragmatism, soft regulation, and the economic imperative. Asian Journal of Business Ethics, 2(2), 185-204.

Tice, D. M., \& Baumeister, R. F. (1985). Masculinity Inhibits Helping in Emergencies: Personality Does Predict the Bystander Effect. Journal of Personality and Social Psychology, 49(2), 420-428. 
Tilt, C. A. (2016). Corporate social responsibility research: the importance of context. International Journal of Corporate Social Responsibility, 1(1), 1-9.

Ullmann, A. A. (1985). Data in Search of a Theory: A Critical Examination of the Relationships among Social Performance, Social Disclosure, and Economic Performance of U. S. Firms. The Academy of Management Review, 10(3), 540-557.

Vachon, S. (2010). International operations and sustainable development: Should national culture matter? Sustainable Development, 18(6), 350-361.

Vashchenko, M. (2017). An external perspective on CSR: What matters and what does not? Business Ethics: A European Review, 26(4), 396-412.

Vehkaperä, M. (2004). Corporate social responsibility in CSR reports. Frontiers of e-Business Research, 572-580.

Vitell, S. J., Joseph, G. P. P., \& Thomas, J. L. (2003). The Perceived Role of Ethics and Social Responsibility: A Study of Marketing Professionals. Business Ethics Quarterly, 13(1), 6386.

Waller, D. S., \& Lanis, R. (2009). Corporate Social Responsibility (CSR) Disclosure of Advertising Agencies: An Exploratory Analysis of Six Holding Companies' Annual Reports. Journal of Advertising, 38(1), 109-122.

Wang, J., Tian, G., Fan, W., \& Luo, D. (2017). The effect of mandatory regulation on corporate social responsibility reporting quality: Evidence from China. Journal of Applied Business Research, 33(1), 67-86.

Weber, M. (1978). Basic sociological terms. Economy and society, 1, 3-62.

Welford, R. (2005). Corporate Social Responsibility in Europe, North America and Asia. Journal of Corporate Citizenship, 2005(17), 33-52.

Williams, C. \& Aguilera, R.V. (2008). Corporate Social Responsibility in a Comparative Perspective. In A. Crane, D. Matten, A. McWilliams, J. Moon, \& D. S. Siegel (Eds.) Oxford Handbook of Corporate Social Responsibility (pp. 452-472). Oxford, UK: Oxford University Press.

Williams, S. M. (1999). Voluntary environmental and social accounting disclosure practices in the Asia-Pacific region: An international empirical test of political economy theory. International Journal of Accounting, 34(2), 209-238.

Zahid, M., Ghazali, Z., \& Rahman, H. (2016). Corporate sustainability practices and reporting: A case of Malaysian real estate investment trusts and property listed companies. International Journal of Economics and Financial Issues, 6(2), 688-693. 
Table 1: Mandatory sustainability disclosure in the six countries

\begin{tabular}{|c|c|}
\hline Country & Mandatory sustainability disclosure \\
\hline Indonesia & $\begin{array}{l}\text { - Law No. 40/2007, Article } 66 \text { requires limited liability companies to disclose } \\
\text { information containing environmental and social responsibility programs within } \\
\text { their annual reports. } \\
\text { - Regulation No.KEP-431/BL/2012, } 2012 \text { concerning Annual Reporting for } \\
\text { Publicly Listed Companies: sustainability disclosure should contain labour } \\
\text { practices, product responsibility, social empowerment, as well as policies and } \\
\text { programs of environmental performance. Publicly listed companies can disclose } \\
\text { this information through multiple methods, namely annual reports, separate } \\
\text { sustainability reports or their CSR reports. } \\
\text { - Government Regulation no.47/2012, } 2012 \text { regarding Social and Environmental } \\
\text { Responsibility for Limited Liability Companies. This regulation addresses social } \\
\text { and environmental responsibility as the obligation of companies with business } \\
\text { activities in the area of natural resources; and the implementation of these } \\
\text { responsibilities should be mentioned in their annual reports. } \\
\text { - Regulation No.24/2012, } 2012 \text { by Ministry of Energy and Mineral Resources. The } \\
\text { regulation introduces an annual report template which includes a section for } \\
\text { environmental protection and community development. }\end{array}$ \\
\hline Malaysia & $\begin{array}{l}\text { - The Securities Commission and Bursa Malaysia (the Stock Exchange of Malaysia) } \\
\text { require all listed companies to disclose sustainability in annual reports (2006) }\end{array}$ \\
\hline Philippines & $\begin{array}{l}\text { - Corporate Social Responsibility Act, 2011: the regulation states that all large tax } \\
\text { payer corporations need to disclose sustainability related activities in annual reports } \\
\text { submitted to the Securities and Exchange Commission (SEC). }\end{array}$ \\
\hline Singapore & $\begin{array}{l}\text { - Energy Conservation Act, 2012: Large industries are expected to disclose energy } \\
\text { usage and provide an energy management plan to the government. }\end{array}$ \\
\hline Thailand & $\begin{array}{l}\text { - Principles of good CG, 2002: listed companies need to demonstrate the fifteen } \\
\text { principles of good CG in their annual reports. In } 2013 \text {, the Stock Exchange and } \\
\text { Commission (SEC) published a notification on compulsory disclosure of CSR/ } \\
\text { sustainability policies and information on form } 56-1 \text {, annual reports or in } \\
\text { standalone reports. The regulation was effective in } 2014 \text { and applied to new firm } \\
\text { listings. }\end{array}$ \\
\hline Vietnam & $\begin{array}{l}\text { - In 2015, the Ministry of Finance released the Circular No. } 155 / 2015 / \text { TT-BTC on } \\
\text { Public Disclosure for listed companies, in which a guideline for disclosing } \\
\text { information on securities markets was attached. According to the guideline, all } \\
\text { listed companies, except those operating in finance, banking, securities and } \\
\text { insurance sectors, are required to disclose any impact of their activities on the } \\
\text { environment and society. This includes complying with regulations related to } \\
\text { employees, water and energy consumption, management of raw materials, } \\
\text { responsibility to local community and green capital market activities. }\end{array}$ \\
\hline
\end{tabular}


Table 2: Summary of the hypotheses

\begin{tabular}{|c|c|c|c|c|c|}
\hline $\begin{array}{l}\text { Institutional Pillar } \\
\text { (Scott, 1995) }\end{array}$ & Definition & Mechanism of influencing & Indicators of the pillar & Derived variables & Hypothesis \\
\hline \multirow[t]{2}{*}{ Regulative } & \multirow{2}{*}{$\begin{array}{l}\text { Formal, explicit and legally } \\
\text { sanctioned structures } \\
\text { (Palmer, Biggart \& Dick, } \\
\text { 2013) }\end{array}$} & \multirow[t]{2}{*}{$\begin{array}{l}\text { Monitoring and enforcement } \\
\text { (North, 1990) }\end{array}$} & $\begin{array}{l}\text { Legal system (Barakat, Perez \& } \\
\text { Ariza, 2015) }\end{array}$ & $\begin{array}{l}\text { Civil Law/ Common Law (La Porta } \\
\text { et al., 2008) }\end{array}$ & 1 \\
\hline & & & $\begin{array}{l}\text { Existence of government } \\
\text { regulations (Campbell, 2007; Kim } \\
\text { et al., 2013; Scott, 2008) }\end{array}$ & $\begin{array}{l}\text { Mandatory sustainability disclosure } \\
\text { (Wang et al., 2017) }\end{array}$ & 2 \\
\hline \multirow[t]{2}{*}{ Cultural-cognitive } & \multirow{2}{*}{$\begin{array}{l}\text { Shared beliefs, social } \\
\text { knowledge and taken for } \\
\text { granted assumptions (Scott, } \\
\text { 2004) }\end{array}$} & \multirow{2}{*}{$\begin{array}{l}\text { Social pressures and } \\
\text { conformity (Shnayder et al., } \\
\text { 2016) }\end{array}$} & \multirow[t]{2}{*}{ Culture (Peng, 2009) } & $\begin{array}{l}\text { Uncertainty Avoidance (Bowrin, } \\
\text { 2013; Williams, 1999) }\end{array}$ & 3 \\
\hline & & & & $\begin{array}{l}\text { Masculinity (Bowrin, 2013; } \\
\text { Williams, 1999) }\end{array}$ & 4 \\
\hline \multirow[t]{2}{*}{ Normative } & \multirow[t]{2}{*}{$\begin{array}{l}\text { Shared norms and values } \\
\text { (Scott, 2013) }\end{array}$} & \multirow[t]{2}{*}{$\begin{array}{l}\text { Normative processes }-\mathrm{a} \\
\text { system of soft laws (Scott, } \\
2013 \text { ) }\end{array}$} & $\begin{array}{l}\text { External standards (Christmann \& } \\
\text { Taylor, 2006; Shnayder et al., } \\
\text { 2016) }\end{array}$ & $\begin{array}{l}\text { The adoption of Global Reporting } \\
\text { Initiative (GRI) (Barkemeyer, } \\
\text { Preuss \& Lee, 2015; Etzion \& } \\
\text { Ferraro, 2010; Levy et al., 2010) }\end{array}$ & 5 \\
\hline & & & $\begin{array}{l}\text { Professional networks } \\
\text { (Galaskiewicz, 1991; Hoffman, } \\
\text { 1999) }\end{array}$ & $\begin{array}{l}\text { Membership of business } \\
\text { associations (Campbell, 2007; } \\
\text { Galaskiewcz, 1991) }\end{array}$ & 6 \\
\hline
\end{tabular}


Table 3: Variables, measurements and data source

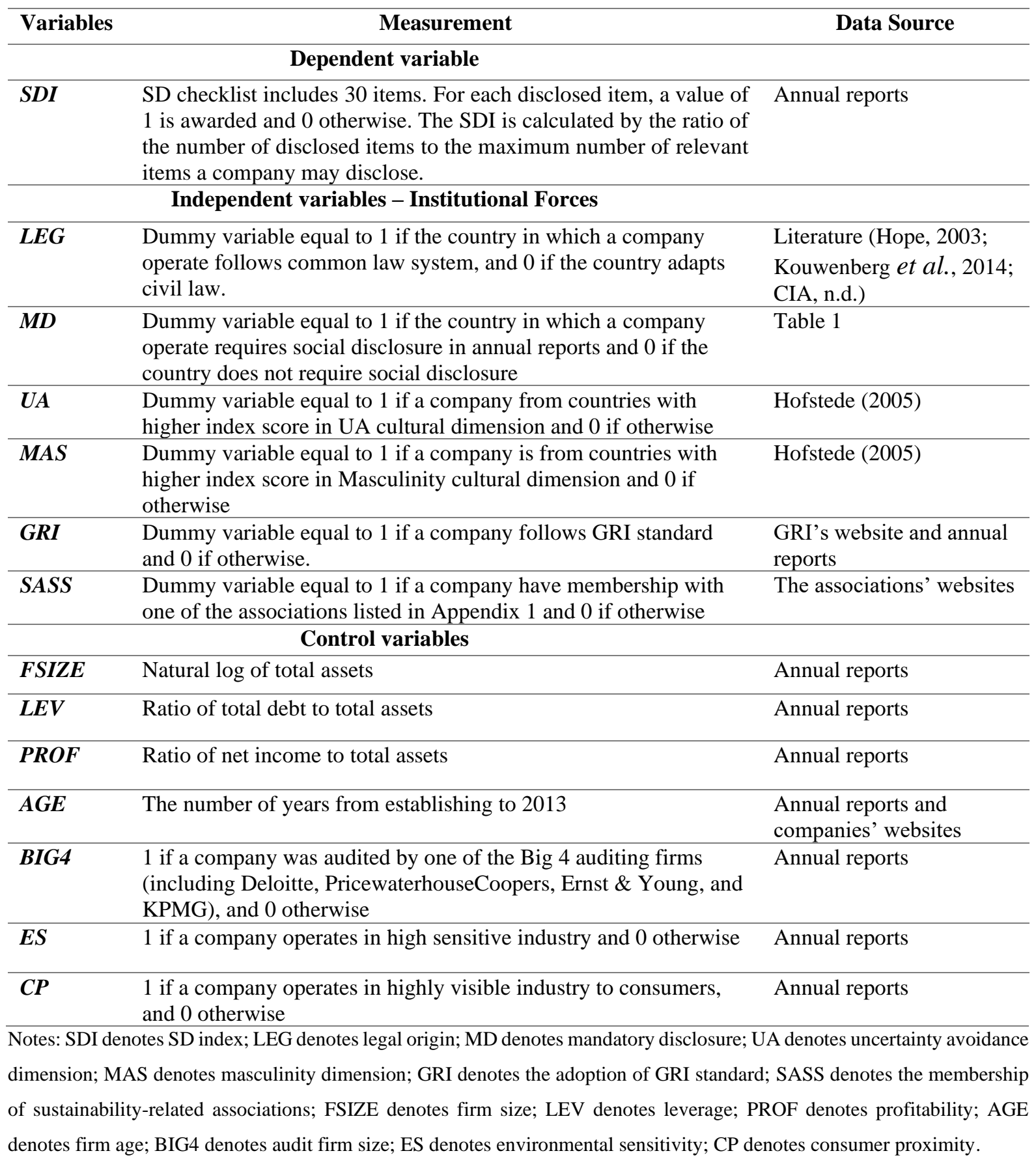


Table 4: Descriptive results of disclosure indices across the six countries

\begin{tabular}{|c|c|c|c|c|c|c|c|}
\hline & All & Indonesia & Malaysia & Philippines & Singapore & Thailand & Vietnam \\
\hline \multicolumn{8}{|c|}{ Panel A: Sustainability Disclosure Index (SDI) } \\
\hline Mean & 0.440 & 0.552 & 0.459 & 0.326 & 0.427 & 0.554 & 0.302 \\
\hline Median & 0.467 & 0.575 & 0.500 & 0.267 & 0.433 & 0.592 & 0.267 \\
\hline SD & 0.204 & 0.162 & 0.155 & 0.208 & 0.167 & 0.192 & 0.194 \\
\hline Minimum & 0.000 & 0.267 & 0.167 & 0.033 & 0.000 & 0.000 & 0.000 \\
\hline Maximum & 0.917 & 0.875 & 0.750 & 0.800 & 0.700 & 0.917 & 0.792 \\
\hline$\%$ of disclosing companies & 97.1 & 100 & 100 & 100 & 92.3 & 96.7 & 93.1 \\
\hline \multicolumn{8}{|c|}{ Panel B: Environmental Disclosure Index (EDI) } \\
\hline Mean & 0.392 & 0.448 & 0.433 & 0.323 & 0.415 & 0.514 & 0.213 \\
\hline Median & 0.364 & 0.455 & 0.455 & 0.273 & 0.454 & 0.591 & 0.090 \\
\hline SD & 0.267 & 0.232 & 0.240 & 0.266 & 0.216 & 0.262 & 0.288 \\
\hline Minimum & 0.000 & 0.091 & 0.000 & 0.000 & 0.000 & 0.000 & 0.000 \\
\hline Maximum & 1.167 & 1.000 & 1.000 & 0.909 & 1.000 & 1.167 & 1.000 \\
\hline$\%$ of disclosing companies & 86 & 100 & 93.1 & 85.2 & 92.3 & 90 & 55.2 \\
\hline \multicolumn{8}{|c|}{ Panel C: HR Disclosure Index (HRDI) } \\
\hline Mean & 0.498 & 0.659 & 0.475 & 0.288 & 0.530 & 0.622 & 0.391 \\
\hline Median & 0.556 & 0.722 & 0.444 & 0.222 & 0.556 & 0.667 & 0.333 \\
\hline SD & 0.273 & 0.228 & 0.210 & 0.304 & 0.258 & 0.210 & 0.253 \\
\hline Minimum & 0.000 & 0.222 & 0.111 & 0.000 & 0.000 & 0.000 & 0.000 \\
\hline Maximum & 1.000 & 1.000 & 0.889 & 0.889 & 1.000 & 0.889 & 0.889 \\
\hline$\%$ of disclosing companies & 91.2 & 100 & 100 & 70.4 & 92.3 & 93.3 & 89.7 \\
\hline \multicolumn{8}{|c|}{ Panel D: Products and Consumers Disclosure Index (PCDI) } \\
\hline Mean & 0.286 & 0.370 & 0.284 & 0.187 & 0.165 & 0.527 & 0.153 \\
\hline Median & 0.200 & 0.400 & 0.250 & 0.200 & 0.000 & 0.600 & 0.000 \\
\hline SD & 0.263 & 0.265 & 0.197 & 0.222 & 0.227 & 0.253 & 0.196 \\
\hline Minimum & 0.000 & 0.000 & 0.000 & 0.000 & 0.000 & 0.000 & 0.000 \\
\hline Maximum & 1.000 & 1.000 & 0.750 & 0.800 & 0.800 & 1.000 & 0.600 \\
\hline$\%$ of disclosing companies & 66.7 & 80 & 82.8 & 51.9 & 46.2 & 90 & 44.8 \\
\hline \multicolumn{8}{|c|}{ Panel E: Community-involvement Disclosure Index (CDI) } \\
\hline Mean & 0.581 & 0.760 & 0.648 & 0.548 & 0.538 & 0.553 & 0.428 \\
\hline Median & 0.600 & 0.800 & 0.800 & 0.600 & 0.600 & 0.600 & 0.400 \\
\hline $\mathrm{SD}$ & 0.280 & 0.177 & 0.254 & 0.246 & 0.245 & 0.363 & 0.255 \\
\hline Minimum & 0.000 & 0.400 & 0.000 & 0.000 & 0.000 & 0.000 & 0.000 \\
\hline Maximum & 1.000 & 1.000 & 1.000 & 1.000 & 1.000 & 1.000 & 0.800 \\
\hline$\%$ of disclosing companies & 91.8 & 100 & 96.6 & 96.3 & 92.3 & 83.3 & 82.3 \\
\hline
\end{tabular}


Table 5: Distribution of cases in institutional variables

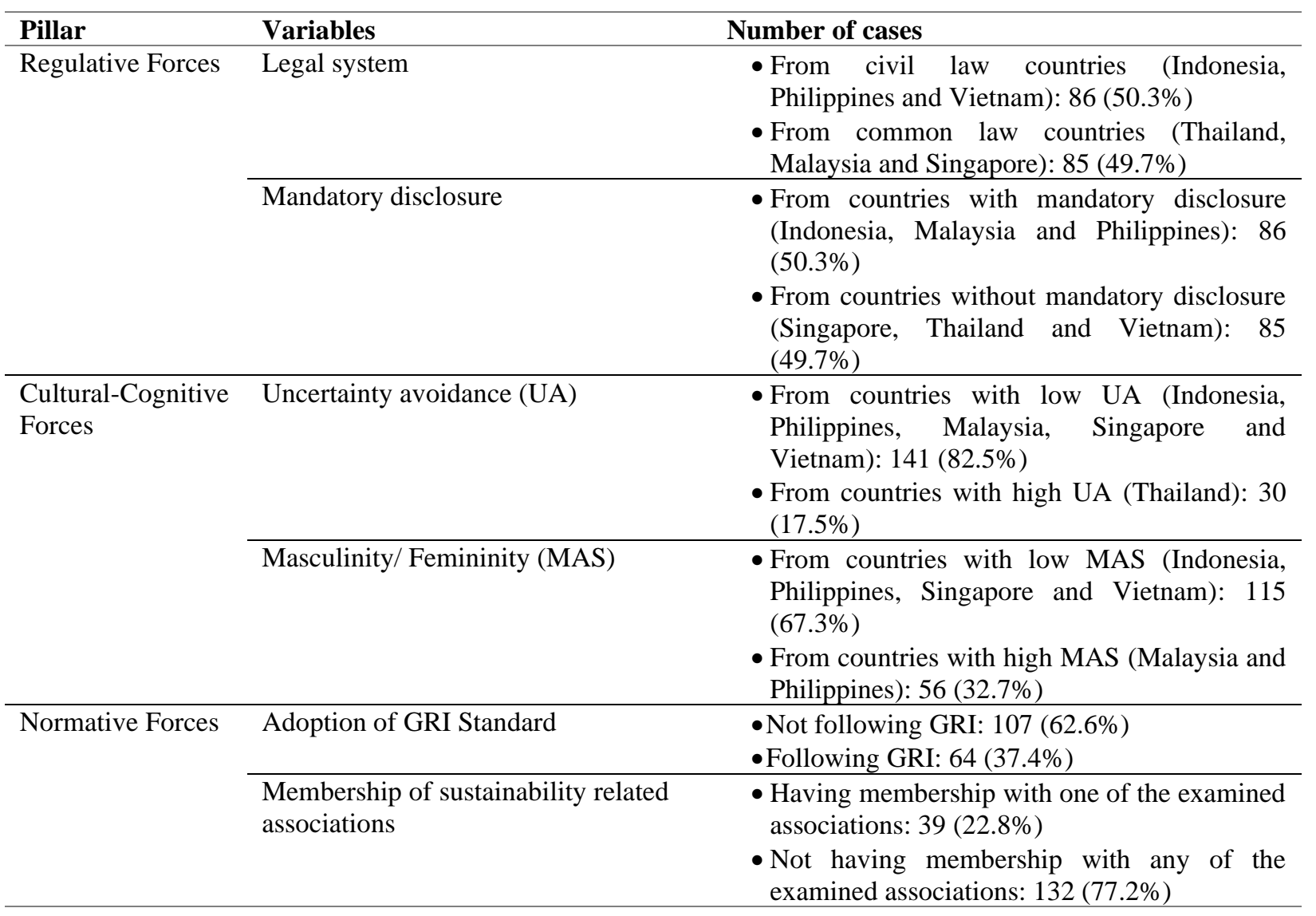


Table 6: Correlations between the variables in the regression model (1)

\begin{tabular}{|c|c|c|c|c|c|c|c|c|c|c|c|c|c|c|}
\hline VARIABLES & SDI & LEG & MD & UA & MAS & GRI & SASS & FSIZE & LEV & PROF & AGE & BIG4 & $\mathbf{C P}$ & ES \\
\hline SDI & & $.206^{* * * *}$ & .054 & $.260^{* * * *}$ & $-.159^{* *}$ & $.406^{* * *}$ & .105 & $.187^{* *}$ & $.199^{* * * *}$ & -.014 & $.185^{* *}$ & $.293^{* * *}$ & .051 & -.031 \\
\hline LEG & $.202^{* * *}$ & & $-.313^{* * *}$ & $.454^{* * *}$ & .038 & $.235^{* * *}$ & $.265^{* * *}$ & $.374^{* * * *}$ & .083 & -.081 & .051 & $.411^{* * *}$ & .053 & $-.142 *$ \\
\hline MD & .063 & $-.313^{* * *}$ & & $-.454^{* * *}$ & $.692^{* * * *}$ & .011 & -.066 & .113 & -.051 & .125 & $.352^{* * *}$ & $-.329^{* * *}$ & .112 & .045 \\
\hline $\mathbf{U A}$ & $.243^{* * *}$ & $.454^{* * *}$ & $-.454^{* * * *}$ & & $-.314^{* * *}$ & $.156^{* *}$ & $.179^{* *}$ & -.015 & $.161^{* *}$ & -.014 & .011 & $.151^{*}$ & .093 & .018 \\
\hline MAS & -.147 & .038 & $.692^{* * *}$ & $-.314^{* * *}$ & & -.014 & .073 & $.237^{* * * *}$ & .032 & -.040 & $.249^{* * *}$ & $-.368^{* * *}$ & $.197^{* *}$ & .029 \\
\hline SASS & .104 & $.265^{* * *}$ & -.066 & $.179^{* *}$ & .073 & $.472^{* * * *}$ & & $.258^{* * * *}$ & $.179^{* *}$ & -.040 & $.149 *$ & .022 & $.195^{* *}$ & .100 \\
\hline FSIZE & $.223^{* * *}$ & $.382^{* * *}$ & $.130^{*}$ & -.012 & $.234^{* * *}$ & $.251^{* * * *}$ & $.254^{* * *}$ & & $.407^{* * * *}$ & $-.573^{* * *}$ & $.345^{* * *}$ & $.164^{* *}$ & $.254^{* * *}$ & $-.145^{*}$ \\
\hline LEV & $.197^{* * *}$ & .069 & -.045 & $.152^{* *}$ & .006 & $.148^{*}$ & $.172^{* * *}$ & $.427^{* * * *}$ & & $-.502^{* * *}$ & $.259^{* * * *}$ & -.004 & $.390^{* * * *}$ & -.133 \\
\hline PROF & -.007 & -.013 & .098 & .030 & -.032 & .067 & .051 & $-.465^{* * *}$ & $-.226^{* * *}$ & & -.109 & .003 & -.072 & .021 \\
\hline AGE & $.137^{*}$ & .019 & $.298^{* * *}$ & -.024 & $.246^{* * *}$ & .113 & $.132^{*}$ & $.344^{* * * *}$ & $.234^{* * *}$ & .019 & & -.029 & $.164^{* *}$ & $-.164^{* *}$ \\
\hline BIG4 & $.306^{* * *}$ & $.411^{* * * *}$ & $-.329^{* * *}$ & $.151^{*}$ & $-.368^{* * *}$ & $.135^{*}$ & .022 & $.181^{* *}$ & .022 & .045 & .010 & & .071 & $-.233^{* * *}$ \\
\hline ES & -.032 & $-.142^{*}$ & .045 & .018 & $.029^{*}$ & .067 & .100 & $-.142^{*}$ & $-.168^{* *}$ & -.113 & -.096 & $-.233^{* * *}$ & $-.306^{* * *}$ & \\
\hline
\end{tabular}

Notes: The bottom left half provides Pearson's parametric correlation coefficients, whereas the upper right half contains Spearman's non-parametric correlation coefficients. SDI denotes SD index; LEG denotes legal origin; MD denotes mandatory disclosure; UA denotes uncertainty avoidance dimension; MAS denotes masculinity dimension; GRI denotes the adoption of GRI standard; SASS denotes the membership of sustainability related associations; FSIZE denotes firm size; LEV denotes leverage; BIG4 denotes audit firm size; CP denotes consumer proximity; ES denotes environmental sensitivity; PROF denotes profitability; AGE denotes firm age. ***, ** and * indicate significance at 0.01 and 0.05 level, respectively. 
Table 7: Empirical results of the regression model

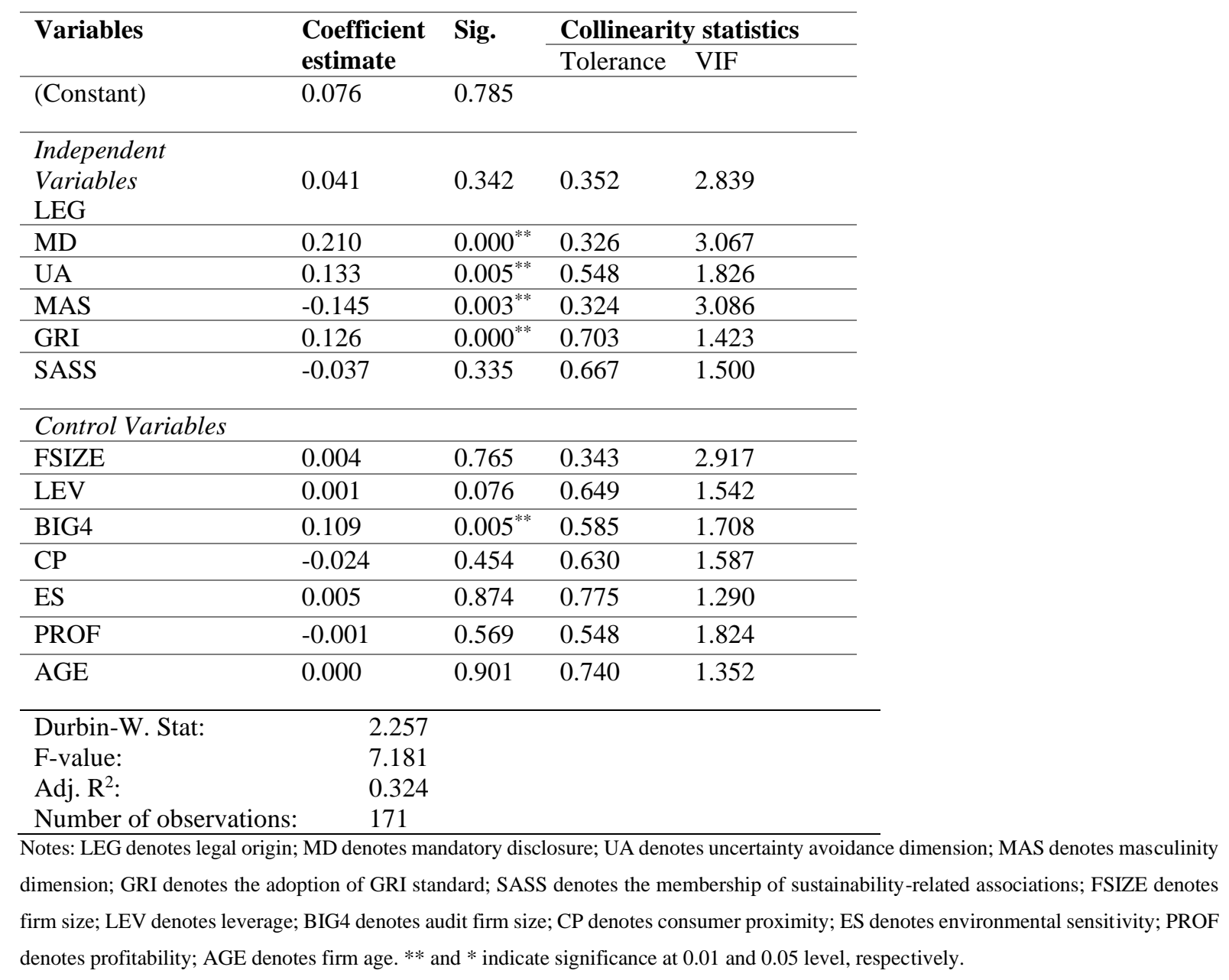


Table 8: Summary of the findings

\begin{tabular}{llccccc}
\hline Institutional pillar & Representing variable & Hypothesis & $\begin{array}{c}\text { Predicted } \\
\text { sign }\end{array}$ & $\begin{array}{c}\text { Sign of } \\
\text { coefficient }\end{array}$ & P-value & Hypothesis confirm \\
\hline Regulative pillar & Legal system & 1 & + & + & 0.342 & Not Confirm \\
\cline { 2 - 6 } & Mandatory regulation & 2 & + & + & $0.000^{* *}$ & Confirm \\
\hline Cultural-cognitive pillar & Uncertainty Avoidance & 3 & - & + & $0.005^{* *}$ & Not Confirm \\
\cline { 2 - 6 } & Masculinity & 4 & - & - & $0.003^{* *}$ & Confirm \\
\hline Normative pillar & GRI standard & 5 & + & + & $0.000^{* *}$ & Confirm \\
\cline { 2 - 6 } & Business association & 6 & + & - & 0.335 & Not Confirm \\
\hline
\end{tabular}


Table 9: Summary of results based on SD sub-indices and weighted SDI

\begin{tabular}{|c|c|c|c|c|c|}
\hline Independent variable & EDI & HRDI & PCDI & CDI & W-SDI \\
\hline (Model) & (2) & (3) & (4) & $(5)$ & (6) \\
\hline $\begin{array}{l}\text { Institutional variables } \\
\text { LEG } \\
\text { MD } \\
\text { UA } \\
\text { MAS } \\
\text { GRI } \\
\text { SASS }\end{array}$ & $\begin{array}{l}0.028(.654) \\
0.139(.033)^{* *} \\
0.150(.027)^{* *} \\
-0.055(.424)^{*} \\
0.182(.000)^{* * *} \\
-0.039(.477)\end{array}$ & $\begin{array}{l}0.103(.079)^{*} \\
0.243(.000)^{* * *} \\
0.053(.398) \\
-0.258(0.000)^{* * *} \\
0.150(0.001)^{* * *} \\
-0.044(.384)\end{array}$ & $\begin{array}{l}0.031(.587) \\
0.208(.000)^{* * * *} \\
0.317(.000)^{* * *} \\
-0.108(.086)^{*} \\
0.141(0.001)^{* * *} \\
-0.088(0.075)^{*}\end{array}$ & $\begin{array}{l}0.019(.769) \\
0.332(.000)^{* * *} \\
0.065(.359) \\
-0.195(.008)^{* * *} \\
-0.027(.575) \\
0.015(.796)\end{array}$ & $\begin{array}{l}0.045(.290) \\
0.231(.000)^{* * *} \\
0.146(0.002)^{* * *} \\
-0.154(0.001)^{* * *} \\
0.111(0.000)^{* * *} \\
-0.039(.295)\end{array}$ \\
\hline $\begin{array}{l}\text { Control variables: } \\
\text { FSIZE } \\
\text { LEV } \\
\text { PROF } \\
\text { AGE } \\
\text { BIG4 } \\
\text { CP } \\
\text { ES }\end{array}$ & $\begin{array}{l}0.023(.230) \\
0.000(.862) \\
0.000(.918) \\
0.000(.956) \\
0.102(.067)^{*} \\
-0.032(.486) \\
0.030(.477)\end{array}$ & $\begin{array}{l}-0.031(.091)^{*} \\
0.003(.000)^{* * *} \\
-0.002(.496) \\
0.001(.300) \\
0.164(.002)^{* * *} \\
-0.024(.587) \\
0.010(.794)\end{array}$ & $\begin{array}{l}-0.015(.399) \\
0.002(.078)^{*} \\
0.001(.677) \\
0.000(.443) \\
0.034(.496) \\
0.023(.581) \\
-0.054(.163)\end{array}$ & $\begin{array}{l}0.037(.075)^{*} \\
-0.001(.202) \\
-0.005(.105) \\
0.000(.869) \\
0.075(.204) \\
-0.033(.509) \\
0.022(.626)\end{array}$ & $\begin{array}{l}0.004(.785) \\
0.001(.169) \\
-0.001(.492) \\
0.000(.986) \\
0.094(.015)^{* *} \\
-0.016(.607) \\
0.002(.940)\end{array}$ \\
\hline $\begin{array}{l}\text { Constant } \\
\text { Durbin-W. Stat } \\
\text { F-value }\end{array}$ & $\begin{array}{l}-0.355(.375) \\
2.063 \\
4.323^{* * *}\end{array}$ & $\begin{array}{l}0.723(.055)^{*} \\
2.131 \\
7.345^{\text {*** }}\end{array}$ & $\begin{array}{l}0.347(.338) \\
2.112 \\
6.450^{* * *}\end{array}$ & $\begin{array}{l}-0.282(.506) \\
2.232 \\
3.682^{* * *}\end{array}$ & $\begin{array}{l}0.108(.692) \\
2.327 \\
6.862^{* * *}\end{array}$ \\
\hline $\begin{array}{l}\text { Adj. } \mathrm{R}^{2} \\
\text { Number of observations }\end{array}$ & $\begin{array}{l}20.5 \% \\
171\end{array}$ & $\begin{array}{l}32.9 \% \\
171\end{array}$ & $\begin{array}{l}29.7 \% \\
171\end{array}$ & $\begin{array}{l}17.2 \% \\
171\end{array}$ & $\begin{array}{l}31.2 \% \\
171\end{array}$ \\
\hline
\end{tabular}

Notes: EDI denotes environmental disclosure index; HRDI denotes human resources disclosure index; PCDI denotes products consumers disclosure index; CDI denotes community disclosure index; W-SDI denotes weighted SD index; LEG denotes legal origin; MD denotes mandatory disclosure; UA denotes uncertainty avoidance dimension; MAS denotes masculinity dimension; GRI denotes the adoption of GRI standard; SASS denotes the membership of sustainability-related associations; FSIZE denotes firm size; LEV denotes leverage; PROF denotes profitability; AGE denotes firm age; BIG4 denotes audit firm size; CP denotes consumer proximity; ES denotes environmental sensitivity.

P-values are in brackets. $* * * * *$ and $*$ indicate significance at $0.01,0.05$ and 0.10 level, respectively 
Table 10: Robustness test using IV regression results

\begin{tabular}{lllll}
\hline Variables & Coeff. & Std. Err. & $\mathbf{z}$ & $\mathbf{P}>\mathbf{z}$ \\
\hline LEG & 0.024 & 0.058 & 0.41 & 0.683 \\
\hline MD & 0.145 & 0.074 & 1.95 & $0.052^{* *}$ \\
\hline UA & 0.107 & 0.059 & 1.82 & $0.069^{* *}$ \\
\hline MAS & -0.092 & 0.065 & -1.41 & 0.157 \\
\hline GRI & 0.425 & 0.164 & 2.59 & $0.010^{* *}$ \\
\hline SASS & -0.219 & 0.228 & -0.93 & 0.350 \\
\hline Constant & 0.387 & 0.389 & 0.99 & 0.321 \\
\hline Number of obs. & 171 & 171 & 171 & 171 \\
\hline Pald chi ${ }^{2}(13)$ & 89.34 & & & \\
\hline Rob $>$ chi $^{2}$ & 0.000 & & & \\
\hline
\end{tabular}

